\title{
A moda no MASP de Pietro Maria Bardi (1947-1987)'
}

\begin{abstract}
Maria Claudia Bonadio ${ }^{2}$
RESUMO: $\bigcirc$ objetivo deste artigo é evidenciar a centralidade das ações ligadas à moda e à formação da Seção de Costumes do MASP no projeto de museu e na concepção de arte de Pietro Maria Bardi no período 1947-1987, e como tais ações teriam sido relevantes para a instituição de uma visualidade e uma história para a moda nacional. Demonstra-se como a trajetória de P. M. Bardi na Itália, ou seja, sua atuação como galerista e comerciante de artes, jornalista, bem como seu contato com a ideologia e as ações do Regime Fascista no campo das artes e da moda, influenciou diretamente suas ações em relação ao design de moda. Essas ideias e experiências foram fundamentais para direcionar sua atuação no MASP e, em especial suas iniciativas na área do design. Nota-se ainda como a atuação de Bardi no campo do design de moda foi também influenciada pelas ideias propagadas pela Bauhaus e Le Corbusier, assim como por seu olhar estrangeiro, que acaba por levá-lo a recuperar, nas referentes iniciativas, as tradições e a cultura brasileiras, gerando uma produção que dialoga com o modernismo brasileiro, uma vez que usa a experiência internacional para valorizar o nacional.
\end{abstract}

PALAVRAS-CHAVE: Museu de Arte de São Paulo (MASP). Pietro Maria Bardi. Moda brasileira. Design de moda. Seção de Costumes.

ABSTRACT: The aim of this article is highlight the centrality of actions related to fashion and the formation of the Costume Section at the São Paulo Museum of Art in Pietro Maria Bardi's project of Museum and his art conception during 1947-1987. I will observe too how such actions were relevant to the proposition of a visual and a history to the national fashion. I will demonstrate, as the trajectory of PM Bardi in Italy, specially his role as gallerist and art dealer, journalist, as his contact with the Facist ideology directly influenced in their actions in the field of fashion and arts, and to his intellectual formation. And, as such ideas and experiences will be key to direct his activities at MASP and in particular as regards the initiatives in the design area. Further notice, as the Bardi's actions in the field of fashion design were also influenced by the ideas propagated by the Bauhaus, and Le Corbusier, as well as its foreign gaze which
1. Artigo resultante de pesquisa financiada pelo CNPq e desenvolvida como pós-doutoramento no Museu Paulista sob a supervisão da profa. dra. Vânia Carneiro de Carvalho. A autora agradece os bibliotecários Ivani $\mathrm{Di}$ Grazia Costa, Maíra Carvalho Moraes e Romeu Loreto da Biblioteca e Centro de Documentação do MASP pela gentileza no atendimento e colaboração com essa pesquisa.

2. Bacharel, mestre e doutora em História pela Unicamp; docente do Departamento de Artes e Design da Universidade Federal de Juiz de Fora. E-mail: <mariacbonadio@ uol.com.br $>$.

Anais do Museu Paulista. São Paulo. N. Sér. v.22. n.2. p. 35-70. jul.- dez. 2014. 
3. Idealizado pela arquiteta Lina Bo Bardi, o IAC funcionou entre março de 1951 e dezembro de 1953 , e ofertava entre outros, cursos de Desenho Industrial e Propaganda. Em seus escritos, Pietro Maria Bardi explica que um dos objetivos da escola era "implementar estudos e pesquisas no terreno das artes aplicadas" adotando uma "orientação contemporânea", e permitir que os objetos cotidianos atingissem "um nível estético elevado". Uma escola de artes aplicadas mantida pelo museu deveria, portanto, contribuir para a "formação de uma consciência clara da função social da arte". Cf: Pietro Maria Bardi (apud Ethel Leon, 2006).

4. Cf. André Stolarsky (2005, p. 37).

5. Ibidem.

6. O texto originalmente denominado Musées hors des limites foi publicado na revista em francês e vertido para o português na biografia de Bardi escrita por Francesco Tentori (2000). No livro o biógrafo aventa que o texto que talvez tenha sido elaborado para apresentação em algum congresso ou evento internacional e mantido na língua original quando da publicação no Brasil

7. Cf. Pietro Maria Bardi (apud Franceso Tentori, 2000, p. 189).

8. Cf. Francesco Tentori (2000, p. 190).

9. Idem (p. 191) ultimately lead him to recover in initiatives relating to design the Brazilian culture and traditions, which ends up generating a production that dialogues with Brazilian modernism, since it uses international experience to enhance the national.

KEYWORDS: São Paulo Art Museum (MASP). Pietro Maria Bardi. Brazilian Fashion. Fashion Design. Costume Department.

Um museu fora dos limites

No início da década de 1950, Alexander Wollner (1928-) - hoje um dos mais conhecidos designers do país - era aluno do Instituto de Arte Contemporânea (IAC) do MASP3. Em certa ocasião, observou que, numa vitrine do museu (que então funcionava no prédio dos Diários Associados à Rua Sete de Abril, no centro de São Paulo) repleta de potes egípcios, astecas e outras antiguidades, havia também uma máquina de escrever Olivetti. Intrigado com a mistura inusitada foi falar com Flávio Motta, assistente de seu professor e diretor do museu Pietro Maria Bardi: "Acho que esqueceram uma máquina de escrever na vitrine $(. . .)^{\prime 4}$. Diante da questão ouviu do próprio Bardi que a "máquina de escrever era a mesma coisa que o pote na época do pote: um objeto útil, que fazia parte da cultura de um grupo primitivo, assim como a máquina hoje faz parte do nosso grupo" ${ }^{\prime}$.

$\bigcirc$ episódio relatado por Wollner revela alguns dos pontos cruciais da concepção de P. M. Bardi acerca das funções do museu, claramente expostas no artigo - uma espécie de manifesto - de sua autoria intitulado "Museu fora dos limites" e publicado no número 4 da revista Habitato:

No mesmo texto, explica que os museus contribuíram para a separação

É preciso conceber novos museus, fora dos limites estreitos e de prescrições da museologia tradicional: organismos em atividade, não com o fim estreito de informar, mas de instruir, não uma coleção passiva de coisas, mas uma exposição contínua e uma interpretação de civilização (... $)^{7}$.

das artes, mas que, em sua concepção, um museu deveria promover justamente o contrário, a unidade das artes, que, para ele, significaria "participação da arte na sociedade e contribuição para sua sistematização futura", e propõe uma reformulação dos museus de modo que eles "sirvam às pessoas, que orientem a formação de seu gosto, que as coloquem diante do antigo, ou seja, diante das premissas de sua própria vida, para dali tirar energias vitais úteis para o futuro $(. . .)^{\prime \prime} 8$, Para ele, nesse "antimuseu", atividades como a história da pintura poderiam "representar o mesmo interesse que um espetáculo e certamente o espectador se divertiria"9.

Prossegue explanando que o museu deveria se distanciar dos modelos europeus, instalados em prédios históricos e em geral muito especializados. Em sua opinião, essa instituição deveria ter um caráter "universal e didático", especialmente num "país novo como o Brasil, onde a fundação de museus estava no início".

Partindo dessa concepção de museu, P. M. Bardi, com o apoio de sua segunda esposa, a arquiteta Lina Bo Bardi, irá realizar no MASP algumas ações 
bastante relevantes para o campo do design, como a implantação, em 1951, do Instituto de Arte Contemporânea (IAC), e, ainda a partir desse mesmo ano, a criação de uma coleção de indumentária lou Seção de Costumes, como Bardi preferia chamá-la) e a realização de dois desfiles de moda - um dos quais com toda a coleção projetada nas oficinas do museu e com vistas à comercialização.

Dentre as ações acima citadas, apenas o IAC recebeu um estudo mais aprofundado $^{10}$. Já a formação do acervo de indumentária, os desfiles de moda realizados no museu e a criação de uma coleção com 50 peças de roupas elaboradas em suas oficinas, embora tenham sido mencionados e brevemente relatados em trabalhos como os de Braga e Prado (2011) e Sant'Anna (2010), não foram investigados com o cuidado que merecem ${ }^{11}$. $\bigcirc$ objetivo deste artigo é evidenciar a centralidade das ações ligadas à moda e à formação da Seção de Costumes no MASP no projeto de museu e na concepção de arte de Pietro Maria Bardi. Ainda será observado como tais ações foram relevantes para a instituição de uma visualidade e uma história para a moda nacional, que, por sua vez, expressa parte dos ideais propagados pelos artistas modernistas brasileiros.

No decorrer desse texto, procuro demonstrar como a trajetória de P. M. Bardi na ltália influiu diretamente em suas ações no campo da moda. Ou seja, a importância de sua atuação como galerista e comerciante de artes, jornalista, bem como de seu contato com a ideologia e as ações do Regime Fascista no campo das artes e da moda para sua formação intelectual. E ainda como tais ideias e experiências serão mais adiante fundamentais para direcionar sua atuação no MASP, em particular, no que diz respeito às iniciativas na área do design ${ }^{12}$.

Percebo, igualmente, como essa atuação de Bardi no campo do design de moda foi influenciada pelas ideias propagadas pela Bauhaus e pelo pensamento de Le Corbusier.

\section{Pietro Maria Bardi: Um homem sem especialidades}

Quando P. M. Bardi faleceu, em outubro de 1999, os principais jornais de São Paulo dedicaram grande espaço à sua biografia e ações no país. No jornal Folha de S. Paulo, a trajetória e o legado de Bardi foram tema da llustrada, o caderno de cultura da publicação, e a repercussão de sua morte comentada por personalidades de diversas áreas culturais ${ }^{13}$. Já na imprensa italiana o fato passou quase despercebido, tendo apenas o jornal La Stampa de Turim publicado uma pequena notícia sobre o acontecimento ${ }^{14}$.

Os anos em que Bardi viveu na ltália foram também "esquecidos" por ele, posto que, nas entrevistas que concedeu (e às quais tive acesso), os tempos passados em sua terra natal eram relatados de forma muito panorâmica, sem maiores detalhes. Costumava dizer que havia trabalhado em uma série de jornais, atuado como galerista de arte, sem se alongar acerca de suas ações e convicções ideológicas.
10. Cf. Ethel Leon (2006).

11. Cf. André Luis Prado e João Braga (2012) e Patrícia Sant'anna (2010).

12. Cabe, neste ponto, apontar as diferenças e as conexões entre moda e design. Durante muito tempo, a moda foi entendida como uma área dissociada do design. A associação mais direta entre os processos de criação e produção de moda com o design só ocorreria no Brasil por determinação do MEC em 2002, "a partir das Diretrizes Curriculares Nacionais do Curso de Graduação em Design, consolidadas na Resolução CNE/CES $\mathrm{n}^{\circ}$ 05, de 8 de março de 2004". Só a partir da publicação desse documento, os cursos de graduação começaram a realizar ajuste nas grades curriculares (até então, denominados e concebidos, em sua maioria, como Estilismo), a fim de "manterem o direito de funcionar e conquistarem reconhecimento social" (Bastian, Luz Garcia Neira e Souza, 2008). Nos anos 1950, não só a moda não era pensada como parte do design, como a maior preocupação por parte da indústria têxtil e de confecção era na medida do possível (posto que muito do equipamento era obsoleto) andar passo a passo com a moda internacional, o que significava imitar de perto padronagens e modelos, mudando um ou outro detalhe. Para as estamparias, por exemplo, era comum contratar artistas plásticos que tivessem habilidade para imitar os desenhos usados nos têxteis internacionais. Já para as lojas de luxo, como a Casa Canadá no Rio de Janeiro e Casa Vogue em São Paulo, o segredo do sucesso era comprar lá fora as novidades da alta-costura parisiense, e revender aqui 
- no caso da loja carioca, não sem antes analisar e copiar o modelo em outros tecidos e com alteração em alguns detalhes para vender a alguma elegante brasileira com a etiqueta Canadá de Luxe (Ver Fernanda Queiroz, 1998 e Cristina Seixas, 2002). Faltam estudos que tratem da moda comercializada pelas lojas de departamento nacionais como o Mappin, a Casa Slopper e outras que atendiam às camadas médias da população, mas, levando em conta os estudos sobre a indústria $\mathrm{e}$ as casas de luxo, é possível supor que, para essas, o caminho mais seguro fosse vender ali modelos que também seguissem de perto a moda parisiense, só que a um custo mais acessível. Prática igualmente adotada por modistas e costureiras. Ver Wanda Maleronka (2007).

13. Folba de S. Paulo (02/10/1999, p. 2). Em $O$ Estado de S. Paulo, três páginas do Caderno 2 foram dedicadas a Bardi.

14. Cf. Francesco Tentori (2000).

15. Cf. Monique Augras (1997, p. 28).

16. Folba de S. Paulo (09/12/1983, p. 37).
Levando-se em conta que "todo testemunho é, antes de mais nada, autobiográfico" e, portanto, "[i]mplica na rearrumação de várias lembranças", a partir do momento em que a pessoa é convidada a dar um depoimento, ou, a exemplo, uma entrevista, "ela repensa o assunto e aos poucos vai elaborando o seu discurso"15. No caso de Bardi, as lembranças do período na Itália são resumidas de modo a minimizar as conexões entre sua trajetória e o fascismo.

Ainda que estruture os fatos de memória a fim de construir uma identidade pessoal que "apague" a sua ałuação como fascista - embora esta se limite ao campo das proposições do fascio para as artes, indústria e arquitetura, e não haja indícios de que tenha simpatizado no período com qualquer política antissemita proposta pelo regime -, o acompanhamento de sua trajetória permite afirmar que as ideias nacionalistas fascistas foram fundamentais para a sua percepção de mundo, em especial para a sua concepção de arte e museu, bem como para a incorporação da moda ao espaço museológico. Portanto, antes de tratar de sua atuação no Brasil, voltemos aos tempos de Itália.

Neste ponto, cabe perguntar: o que já foi produzido sobre a trajetória de Bardi na ltália? Pouquíssima coisa. Embora tenha vivido mais de 40 anos no país e tenha tido, nesse período, uma atuação importante no campo das artes como veremos adiante -, suas ações na ltália são ainda pouco estudadas. A biografia P. M. Bardi: com as crônicas artísticas do L'Ambrosiano 1930-1933, escrita por Francesco Tentori, publicada, em 1990, na ltália e, em 2000, no Brasil, constitui o único estudo sobre Bardi na ltália. Apesar de ser uma fonte essencial de pesquisa sobre a vida de Bardi, o livro de Tentori adota um tom exagerado, possivelmente influenciado pela escrita do biografado. E se bem não apague o passado fascista de Bardi, posto que não seria possível tratar de sua juventude e início da vida adulta sem falar de sua simpatia pela ideologia fascista, a biografia o apresenta como uma experiência positiva e desprovida de conflitos.

Pietro Maria Bardi nasceu em 1900, em La Spezia, no norte da Itália. Era o segundo de quatro irmãos. Repetiu por três vezes a terceira série elementar (equivalente ao nosso terceiro ano do Ensino Básico). Acabou sendo "mandado embora da escola" 16 e nunca mais voltou. Conforme seus relatos, teria se tornado inteligente, após uma queda ocorrida dentro de casa e a fortíssima hemorragia que se seguiu.

Na juventude trabalhou como operário ajudante no Arsenalle Marittimo e copista em um escritório de advocacia ainda na cidade de La Spezia. Por volta dos 13 ou 14 anos passou não só a ler, mas a estudar por conta própria. Aos 16 anos, por exemplo, estudava latim de forma autodidata. Em 1917, publicou Dei Possedimenti Coloniale, pela Libreria Editrice Avanti! de Milão, um pequeno livreto sobre o filósofo inglês Jeremy Bentham (1748-1832).

Nos anos subsequentes serviria ao Exército, e, segundo seus próprios relatos, em um grupo de maioria analfabeta, era considerado o "educado". Após receber baixa do serviço militar, seguiu para Dalmine. Nessa cidade, em 20 de março de 1919, assistiu ao discurso de Mussolini durante um protesto de 
trabalhadores na fábrica Franchi e Gregorini, tendo tido, assim, seu primeiro contato com as ideias fascistas. No mesmo ano, passou a trabalhar na redação do Giornale de Bergamo e nos próximos anos se firmaria na carreira de jornalista, atuando em diversos outros jornais e escrevendo sobre os mais variados assuntos.

Em 1924 casou-se com Gemma Tartarolo e teve sua primeira filha Elisa (em 1927, nasceria Fiorella) ${ }^{17}$. Apesar das mudanças na vida pessoal, são as transformações de cunho profissional que terão mais peso em sua trajetória. Ainda em 1924 mudou-se para a cidade de Milão, onde a partir de 1926 passa a atuar no campo das artes como galerista independente. Em 1928, criou o Boletim de Arte editado pela Galleria Bardi S/A, aberta no mesmo ano. No ano seguinte, "quando já havia saído cerca de uma dúzia de boletins da Galleria Bardi", colocou em circulação um jornal de arte de grande formato denominado Belvedere ${ }^{18}$.

É neste jornal que passará a defender a ideia de que não faz sentido dividir a arte em categorias, especialmente em arte antiga ou moderna, pois a "arte é apenas ela mesma" - como exposto anteriormente, anos mais tarde, este será um dos pontos fundamentais em sua percepção acerca da função dos museus ${ }^{19}$. $\bigcirc$ Belvedere foi também o espaço para o posicionamento político de Bardi, que desde 1926 era filiado ao Partido Nacional Fascista.

Na Galleria Bardi, instalada na mesma rua da tradicional Pinacoteca di Brera, P. M. Bardi organizou, entre outras, duas mostras importantes. A primeira, denominada "Seis pintores de Turim", reunia trabalhos de artistas que usavam em suas obras uma linguagem contemporânea, nem sempre bem compreendida pelos alunos da "passadista" Academia di Brera, que, por ocasião da mostra, organizaram uma manifestação contra o modernismo do grupo de Turim. A segunda foi uma mostra do futurista Carlos Carrà (1 88 1-1966) e de Ardengo Soffici (1 8791964), pintor de estilo cubista e fascista.

Em 1930, transferiu-se para Roma, onde passa a administrar a Galeria de Arte de Roma, pertencente ao Sindicato Nacional Fascista de Belas-Artes, e cujo programa, de cunho nacionalista, estabelecia: "fazer exposições periódicas de artistas italianos inscritos no Sindicato (...)", os quais podem ser selecionados em mostras regionais com vistas a "divulgar em Roma, o melhor da produção de nossos artistas"; organizar exposições de artistas estrangeiros já reconhecidos, "a fim de desenvolver o campo cultural e promover, ao mesmo tempo, um entendimento com o mundo artístico estrangeiro, muito útil para a penetração da nossa arte para além dos nossos limites; promover manifestações artísticas de interesse excepcional, objetivando criar na Capital um vivo movimento artístico (...); assumir iniciativas que se tornem úteis ao desenvolvimento da arte italiana". Nos tópicos mais adiante, veremos como o programa do sindicato para a galeria influenciaria a percepção e as iniciativas de Bardi para o desenvolvimento do design no Brasil.

De todo modo, em seu trabalho como galerista, tornam-se evidentes algumas das principais características de sua personalidade e atuação, como "a laboriosidade, a tenacidade, o empenho anticonformista pela causa da renovação arquitetônica e artística, mas também (...) sua não especialização"20. Tanto que,
17. Sabe-se pouquíssimo a respeito de sua primeira esposa e suas filhas, com as quais teria perdido o contato após a vinda para o Brasil. Talvez esse seja outro dos fatos que Bardi prefere "apagar" de sua trajetória, possivelmente porque queria ser lembrado a partir de sua união com Lina (o casamento praticamente coincide com o final da Segunda Guerra e, logo, com o rompimento de Bardi com o fascismo), que, para além do casamento, era uma parceria profissional das mais profícuas.

18. Cf. Francesco Tentori (2000, p. 32).

19. Idem (p. 31).

20. Cf. Francesco Tentori (2000, p. 48) 
21. Trata-se, provavelmente, do pintor tcheco Othon Coubine ou Otakar Kubin (1883-1969).

22. Cf. Francesco Tentori (2000, p. 54).

23. A mesa seria uma das peças exibidas na exposição sobre arquitetura italiana que Bardi viria a organizar na Argentina em 1933, mas se perderia na remessa marítima dos painéis expostos na América Latina. Cf. Franceso Tentori (2000).

24. "O racionalismo arquitetônico corresponde a uma tendência introduzida na Europa, no início do século $\mathrm{XX}$, que mantém forte compromisso com as conquistas da estética do cubismo. A experiência da Bauhaus (1919) é decisiva para o desenvolvimento de uma linhagem racionalista no campo da arquitetura. As pesquisas formais e as tendências construtivistas realizadas com o máximo de economia na utilização do solo e na construção; a atenção às características específicas de diferentes materiais (madeira, ferro, vidro, metais etc.), a ideia de que a forma artística deriva de um método, ou problema, previamente definido, o que leva à correspondência entre forma e função e o recurso permanente às novas tecnologias, estão entre os principais postulados da escola criada e dirigida por Walter Gropius (1883 - 1969). O léxico de matriz cubista e construtivista adotado pelos arquitetos traz o uso sistemático de formas elementares na composição arquitetônica de modo a obter simetria, equilíbrio e regularidade no conjunto projetado. A utilização de materiais novos, a estrutura aparente, as coberturas planas, o despojamento da ornamentação, as grandes superfícies envidraçadas e a preocupação com o espaço interno do edifício consti- nos seus primeiros dois anos de galeria, realizou exposições sobre os mais diversos temas, como uma mostra de pintores estrangeiros - Maurice Utrillo (1883-1955), Moïse Kisling (1891-1953) e Cubine21; uma exposição de metais leves italianos para utilização na arquitetura; uma mostra de cenografia moderna; a exposição de dois jovens artistas toscanos - Giuseppi Cesetti (1902-1990) e Achille Lega 1899-1934); uma mostra de edificação e arquitetura rural; uma mostra de cartazes publicitários; a exposição de escolas de arte ligadas ao Ministério da Educação; a exposição do pintor Virgilio Guidi (1891-1984) e seus alunos da Academia de Veneza; a mostra dos pintores Umberto Lilloni (1898-1980), Gino Ghiringheli (1898-1964), Oreste Bogliardi (1900-1968) e Christoporo De Amicis (19021987); a mostra de um grupo de 10 pintores jovens venezianos e outra de artes aplicadas.

Em suma, no período em que esteve à frente da galeria, expôs ali não apenas resultados de produções artísticas, mas uma variada gama de coisas, incluindo até mesmo uma mostra sobre aeronáutica. Segundo seu biógrafo Francesco Tentori:

ele não pretendia privilegiar, entre os produtos da modernidade, somente aqueles considerados artísticos, mas em consonância com a política cultural do "L'Ambrosiano" e com as teses expressas por Le Corbusier em Vers une architecture, ele queria exaltar, anunciar, difundir o conhecimento de todos os produtos da modernidade, desde os novos materiais para construção e decoração aos motores de hidroavião. ${ }^{22}$

Paralelamente, Bardi atua como colaborador do jornal milanês L'Ambrosiano, em que relata boa parte das atividades desenvolvidas na galeria. Mas foi em Belvedere que se noticiou a "Mostra dos Racionalistas" sobre arquitetura racional, exibida na Galeria de Arte de Roma e na qual Bardi expõe uma colagem denominada "Mesa dos horrores", que reúne imagens de arquitetura acadêmica, de moda, design gráfico e costumes anacrônicos ${ }^{23}$. Em seu entender, todos estes são elementos do mundo das artes, e como tal precisavam se modernizar.

A defesa da arquitetura racional será o tema principal de outra publicação dirigida por Bardi, O Quadrante, publicado entre 1932-193624. Nessa revista foi veiculada uma série de projetos arquitetônicos, dentre os quais o "projeto de um edifício de exposição" criado por Bardi e Guido Fiorini 11897 1966), que sugeria uma galeria de arte "aberta (...) a todos os tipos de exposições, não apenas de realizações artísticas, mas técnicas, de engenharia, científica" 25 , proposta que muito se assemelha às diretrizes adotadas por Bardi, anos mais tarde, para o MASP26. Em 1933, por ocasião da realização do $4^{\circ}$ Congresso Internacional de Arquitetura Moderna (CIAM), Bardi viria a conhecer pessoalmente Le Corbusier (1887- 1965), com quem já se correspondia.

Entre 1936-1938, atuou como jornalista no diário Meridiano e na sequência, entre 1938-1943, dirigiu, escreveu e atuou como designer gráfico para a revista mensal I/ vetro (O vidro), veículo oficial da Federação Fascista de Industriais de Vidro e Cerâmica ${ }^{27}$. 
A última grande empreitada de Bardi antes de sua partida para o Brasil, em 1946, é o Studio d'Arte Palma em Roma, que iria presidir de 1944 a 1949. Tratava-se de, uma galeria que exibia obras de arte antigas e modernas, não somente pintura e escultura, mas "todos os tipos de produção da criatividade humana" ${ }^{28}$; oferecia serviços de perícia e exame científico, além de restaurar obras de arte.

contato com Lina Bo e o desencanto com o fascismo se dão logo após o final da Segunda Guerra, mas são temas sobre os quais a biografia de Bardi é bastante econômica - ainda que ambos sejam bastante relevantes para entender a trajetória que iniciaria no Brasil a partir de dezembro de 1946. Acerca do fascismo, afirma-se apenas que não teria sido fácil para Bardi converter-se à democracia. Em depoimento, Lina relata que, poucos dias após ter conhecido Bardi, conversavam sobre o projeto da revista Politecnico de Elio Vittorini (19081966):

Mostrei a Pietro a lista, feita por Vittorini, dos possíveis colaboradores: e de quase todos ele me explicou os transcursos fascistas, as profundas e múltiplas implicações do regime. Relatei essa conversa a Vittorini que não pestanejou: "Era aquela a vida que fazíamos", me disse, "o fascismo. E não se pode andar contra a vida". ${ }^{29}$

Os preceitos da ideologia fascista são, portanto, indissociáveis da trajetória intelectual de Bardi entre meados dos anos 1920 até a década de 1940. No projeto de Mussolini, a valorização da indústria, da arquitetura, da moda, tanto quanto a da arte italiana eram parte da promoção do ideário nacionalista, e tais percepções se farão sentir no trabalho de Bardi, que desde os tempos da Galeria de Roma demonstrava interesse pelos avanços da indústria e pelo design industrial. Já a arquitetura será não só um dos principais temas de seus escritos, como o próprio Bardi, entre 1935-1943, irá projetar pelo menos três edifícios, um dos quais com uma proposta bastante próxima daquela de Lina Bo Bardi para o MASP inaugurado em $1968^{30}$. No entender de Tentori:

"sistema museográfico", pouco a pouco, está se organizando na mente de Bardi, que nisto lembra Corbusier, também ele propenso ao lento aperfeiçoamento dos modelos simples edificados através dos anos, e sempre com grande coerência ao modelo original. ${ }^{31}$

Anos mais tarde, o vão livre do MASP talvez viesse a ser a maior realização da proposta de Bardi para o "Museu fora dos limites", especialmente por dois motivos: a) integra o museu à paisagem do entorno, preservando a vista da cidade; b) permite a interação do cidadão com o espaço, mesmo sem comprar ingresso e adentrar o museu ${ }^{32}$.

Se o gosto de Bardi pela arquitetura talvez tenha sido influenciado por seu contato com as ideias de Le Corbusier, o entendimento do arquiteto acerca das artes, para quem "A forma artística é o resultado lógico do 'problema bem formulado': os navios a vapor, os aviões, cuja forma corresponde exatamente à função, são belos tuem outros pontos centrais da chamada arquitetura racionalista." (Enciclopédia Itaú Cultural de Artes Visuais, http://www.itaucultural.org.br/aplicexternas/ enciclopedia_ic/index. cfm?fuseaction $=$ marcos texto\&cd_verbete $=4272$. Acesso em: 26 jan. 2014.

25. Francesco Tentori (2000, p. 123).

26. O mesmo ecletismo seria verificado em sua atuação no MASP, como se pode observar no livro História do MASP de Pietro Maria Bardi (1991), no qual há uma listagem das exposições realizadas no museu de 1947 a 1991 , dentre as quais, mostras sobre quadrinhos, cristais, jardinagem, design gráfico, design de móveis, decoração de interiores, charges, arte têxtil, publicidade e até perfumes.

27. A publicação, apesar de ser especialmente voltada para a aplicação do vidro na arquitetura, abarca também temas sobre a utilização do vidro na indústria em geral.

28. Francesco Tentori (2000, p. 163).

29. Francesco Tentori (2000, p. 164).

30. Segundo Tentori, os principais pontos de contato entre o edifício do MASP, projetado por Lina e inaugurado em 1968, e o projeto proposto por Bardi, em 1935, são os seguintes: "um grande salão central circundado por uma galeria de exposição (em São Paulo, são escritórios e arquivos) na qual se evidencia, como forte destaque da parede, a estrutura portante (neste caso, em tirantes de aço; em São Paulo, cabos de aço suspensos pela trave de cobertura)." Cf. Francesco Tentori (2000, p. 157)

31. Ibidem. 
32. Acrescente-se a isso, o projeto de Lina para a Pinacoteca que, sem paredes brancas e com cavaletes transparentes, também remete ao projeto supracitado.

33. Cf. Giulio Carlo Argan (1992, p. 265).

34. Ver Silvana Rubino (2002).

35. A sede definitiva do museu foi inaugurada em 1968 e o evento contou com a presença da rainha Elizabeth da Inglaterra. Tal prédio foi projetado por Lina Bo Bardi seguindo os preceitos de sua arquitetura e as idéias de P.M. Bardi, segundo as quais um museu não deveria ser um espaço isolado, mas integrar-se à cidade, o que, no caso, se dá através do imenso vão livre do prédio, onde acontecem feiras, shows, manifestações e serve ainda como ponto de encontro para muitos cidadãos.

36. A exposição do acervo do MASP realizada em 1953 no Musée de L'Orangerie de Paris pode ser considerada $\mathrm{o}$ primeiro ato em direção ao reconhecimento internacional do museu, posto que, até então, grande parte dos órgãos de imprensa que não pertenciam aos Diários Associados acusava Assis Chateaubriand de estar montando um museu com obras falsas. Assim, a exibição das obras do MASP em uma importante instituição de arte internacional não só colaborou na projeção internacional dessa coleção, como the trouxe mais prestígio dentro do Brasil. como o Parthenon" -, ao valorizar os objetos industriais, também se coadunam com o entendimento do italiano em relação à arte ${ }^{33}$. Tal premissa aproxima-se da concepção de arte de Bardi, que já havia exposto nas galerias em que atuou diversos objetos de design e de engenharia. Avesso ao tratamento diferenciado de uma tipologia única de objeto, para ele a arte deveria ser uma só. Sua tarefa era integrar, assim, os mais diversos campos, nos quais incluía o design e, por conseguinte, a moda.

Museu de Arte

Não é possível precisar os motivos que levaram o então jovem casal Lina Bo e P.M. Bardi a se transferir para o Brasil em dezembro de 1946, mas, como aponta Silvana Rubino ${ }^{34}$, é provável que o forte clima antifascista que se instalou na ltália após o final da Segunda Guerra tenha contribuído para a decisão. Por outro lado, o crescimento industrial pelo qual o país vinha passando interessava a ambos, e, no ver de Tentori, o prestígio desfrutado pela arquitetura brasileira no exterior desde a década de 1930 pode ter pesado na decisão.

Logo após a chegada do casal ao Brasil, P. M Bardi iniciou a promoção de três mostras de arte no Rio de Janeiro: "Exposição de pintura italiana antiga (séculos XIII-XVIII)", "Exposição para objetos de arte para a decoração de interiores" e "Exposição de pintura italiana moderna". Provavelmente, durante uma dessas exposições (todas com propósito comercial), Assis Chateaubriand, então o maior empresário das comunicações do país, viria a conhecer o marchand de artes P. M. Bardi. Na ocasião, Assis Chateaubriand teria exposto ao italiano o desejo de implantar no Brasil um museu que abrigasse obras de arte consagradas, com vistas a inserito no circuito internacional das artes, de forma a evidenciar que o país vinha se desenvolvendo não só no campo econômico e industrial, mas também na área da cultura.

Em 04 de outubro de 1947 foi inaugurado o Museu Arte de São Paulo (MASP), com sede provisória no prédio dos Diários Associados (nome do grupo de comunicação pertencente a Chateaubriand), na Rua Sete de Abril, no centro de São Paulo, e direção de P. M. Bardi - que permaneceria no cargo até $1988^{35}$. Para Chateaubriand, o museu deveria reunir obras-primas da arte europeia, o que em seu entender não seria difícil, pois bastava conseguir entre a alta burguesia nacional dinheiro para adquirir a preço irrisório obras que as famílias ricas europeias se dispunham a vender em razão das agruras sofridas durante a Segunda Guerra. Assim se formou grande parte do acervo do museu, que rapidamente irá se tornar o mais importante museu de arte do hemisfério sul, abrigando peças de artistas consagrados pelo mercado e pela crítica das artes ${ }^{36}$.

O trânsito de Bardi no mercado europeu das artes foi determinante para a constituição do acervo do MASP, mas, como vimos anteriormente, sua percepção em relação à função de um museu de arte extrapolava a simples reunião e exibição de obras de arte já consagradas. No seu entender, o museu deveria ter uma ampla 
atuação no presente, e ser voltado não exclusivamente para determinada corrente artística, antiga ou moderna, mas focado na arte como um todo.

O Museu de Arte - como Bardi costumava chamar o MASP - deveria ainda colocar o público em contato com a arte, arquitetura e tendências do design de forma a impulsionar a formação profissional nessas áreas ${ }^{37}$. A amplitude e diversidade que o museu podia apresentar eram, para ele, qualidades estratégicas para o desenvolvimento da cidade de São Paulo, que à época firmava-se como metrópole e o mais importante centro econômico do país ${ }^{38}$.

Aos olhos de seu idealizador Assis Chateaubriand, a constituição de um acervo portentoso, repleto de obras consagradas, era a principal meta do MASP, mas, para Bardi, o museu deveria ir além. Assim, de acordo com as premissas acima elencadas, em 1950 foi criada a revista Habitat - Revista das Artes no Brasil, que veiculava o projeto de Bardi para o museu, bem como as ideias de seus colaboradores. Por último, mas não menos importante, entre 1951-1952 viria a funcionar no museu o IAC, a primeira escola de design do Brasil, dirigida por Lina.

Os planos de Bardi para o museu, especialmente no que diz respeito à sua utilização como um espaço para reflexão e produção de objetos de design, certamente encontraram em Lina Bo a principal apoiadora, se não parceira. Foi ela quem encabeçou a direção do IAC e da revista Habitat nos primeiros anos de sua publicação (do número 1 ao número 9), que coincidem com o período das ações apontadas mais adiante ocorridas entre 1950 e $1952^{39}$.

Para Lina os campos do design e do jornalismo não eram novidade, posto que havia se dedicado a tais atividades ainda na Itália, onde atuou como redatora e também ilustradora, aproximando-se, portanto, do design gráfico de revistas. Para a Stile, revista editada por Giò Ponti (1871-1979) - e na qual Bardi era redator - ilustrou capas e "páginas internas sozinha ou a várias mãos", como aquelas em parceria com Ponti, Carlo Pagani e seu pai Enirco Bo ${ }^{40}$. Em 1944, passou a codirigir, ao lado de Giò Ponti, a revista Quaderni di Domus, na qual escrevia sobre a origem da casa moderna "da porta para dentro, ao que tudo indica - e nela eram publicados os melhores exemplos, italianos ou não, de mobiliário e equipamento doméstico". Pouco tempo depois, em 1946, "viajou por toda a Itália, pesquisando artesanato com o fim de organizar uma exposição de têxteis para cortinas e estofamentos para uma empresa italiana, a Rima"4l.

Levando em conta essa trajetória, concordo com Silvana Rubino (2010) quando ela afirma que, não por acaso, poucos anos mais tarde, já no Brasil, Lina se envolveria justo na criação de uma escola de desenho industrial, o IAC no MASP.

Se o acervo do museu, a revista Habitat e o IAC podem ser considerados "O tripé que dava vida ao MASP" em sua primeira fase, duas das pernas desse tripé eram sustentadas pela parceria Bardi e Lina ${ }^{42}$. Tais espaços seriam também utilizados por Bardi para realizar no museu uma série de ações voltadas para a moda a partir de 1950. São elas: a formação de uma Seção de Costumes, a realização de dois desfiles de moda nas instalações do museu, a produção de uma
37. Cf. Pietro Maria Bardi (1951).

38. A partir do final dos anos 1940 e início dos anos 1950, a cidade de São Paulo finalmente atinge a almejada condição de metrópole. Ver Richard Morse (1970). Nesse contexto de desenvolvimento econômico, a cidade passa também a receber novos investimentos em ações culturais, que permitirão a implementação na cidade de novos espaços e grupos, que, de certa forma, irão funcionar como espelho da prosperidade econômica de organizações industriais e de imprensa então instaladas na cidade. Ver Maria Arminda do Nascimento Arruda (2001). Um dos desdobramentos do novo panorama paulistano será a instalação na cidade do MASP e, um ano mais tarde (1948), do Museu de Arte Moderna, viabilizado através do mecenato de Francisco Matarazzo Sobrinho.

39. Lina voltaria a dirigir a revista em conjunto com Bardi no ano de 1954 e mais especificamente para os números 14-18.

40. Alguns desses trabalhos recebiam a assinatura Gienlica, que queria dizer Giò Ponti, Enrico Bo, Lina Bo e Carlo Pagani. Ver Silvana Rubino e Marina Grinover (2010, p. 27).

41. Cf. Silvana Rubino (2010, p. 349).

42. Ver Silvana Rubino e Marina Grinover (2010, p. 29). 
43. As cartas foram enviadas para os seguintes museus: Museu da Cultura Peruana, Museu de arte popular americano, no Chile, Museu Nacional de Arte Hispanoamericano, na Argentina, e Museu Nacional Tihuanacu, na Bolívia.

44. Cf. Desfile de Costumes, Caixa 4,Pasta 23 (Biblioteca e Centro de Documentação do MASP, 1951).

45. Cf.Desfile de Costumes, Caixa 4,Pasta 23 (Biblioteca e Centro de Documentação do MASP, 1951).

46. Segundo Alexandra Palmer (2012), em 1949 havia no Brasil uma boutique da marca Christian Dior, e é possível que essa fosse administrada ou funcionasse dentro da Casa Vogue - essa suposição é feita em razão das ações de Paulo Franco em relação à marca em 1951, posto que não existem maiores pesquisas nem publicações sobre a loja; mesmo o livro História da Moda no Brasil de João Braga e Luís Prado (2011) traz poucas informações sobre o tema. As boutiques Christian Dior vendiam acessórios, perfumes e vestidos para o dia a dia a preços mais modestos que as peças de alta-costura,mas ainda assim voltados para as elites. coleção de moda nas oficinas do IAC,com vistas à comercialização, e a publicação de alguns textos na revista Habitat em prol do desenvolvimento de uma identidade para o design de moda no Brasil.

\section{A Seção de Costumes}

Data de 7 de junho de 1951, uma série de cartas enviadas a museus internacionais, em especial da América Latina, solicitando doações de peças ${ }^{43}$. Nessas cartas, Bardi explica que "El Museu de Arte de São Paulo, instituyo (sic) una séccion del costume que se dedicará muy especialmente a los trajes de Sudamérica". E prossegue informando que, por esse motivo, tomou a liberdade de escrever na esperança de manter uma colaboração com tais instituições, pois pensa que o contato entre os museus do mesmo continente pode trazer benefícios mútuos. Afirma ainda que ficaria muito grato se os responsáveis por esses museus pudessem informar sobre a possibilidade de adquirir, em seus países, peças e trajes de épocas distintas e de diferentes origens ${ }^{44}$.

As cartas enviadas aos museus sul-americanos aparentemente não foram respondidas - se houve alguma resposta, não foi anexada aos documentos referentes à Seção de Costumes - entretanto, essa falta de réplica inicial não parece ter desanimado Bardi, que continuaria investindo esforços na formação de um acervo pelo menos até o final da década de 1980.

É provável que as primeiras indumentárias incorporadas ao acervo do museu sejam cinco vestidos de Christian Dior (1905-1957), supostamente datados do final da década de 1940 ou início da década de 1950. Aventa-se, segundo alguns escritos de Bardi, que tenham sido doados por Paulo Franco lentão proprietário da Casa Vogue - uma das mais renomadas casas de moda de luxo de São Paulo - e importante colaborador de Bardi no projeto de formação dessa seção).

Em carta datilografada, de 27 de março de 1951, e presumivelmente redigida com vistas à divulgação na imprensa do "Desfile de Costumes Antigos e Modernos", Bardi solicita doações de indumentárias antigas à sociedade paulistana e informa que Paulo Franco "num gesto de benemerência (...) espontaneamente acaba de doar uma rica coleção de costumes antigos"45. Levando em conta que os trajes mais antigos, pertencentes ao acervo do MASP, datam da década de 1920 e só foram doados vinte anos mais tarde, é possível que Bardi estivesse se referindo às peças de Christian Dior, provavelmente as primeiras das coleções do costureiro e, por isso, denominadas "costumes antigos".

Além disso, foi Paulo Franco quem viabilizou o desfile que a marca Dior faria no museu em 1951, e por sua condição de proprietário de uma importante loja de moda tinha amplo conhecimento da alta-costura e acesso às peças, que costumava comprar para revender em sua loja ${ }^{46}$.

Outra peça que chega ao acervo do museu logo no início da década de 1950 é o Costume de 2045. A indumentária, mais uma doação de Paulo 
Franco, teria sido desenhada por Salvador Dalí, em 1949, e "confeccionado em São Paulo na Casa Dior pelo costureiro russo Karinska". "Segundo uma matéria publicada no Jornal da Tarde em 1986, o Costume teria sido desenhado especialmente para o MASP, a partir de um pedido de Pietro Maria Bardi, diretor do Museu, a Paulo Franco" 47.

Ao que indicam as fontes, são essas as peças que vão compor a Seção de Costumes do museu até o início da década de 1970, quando, em 1971, ocorre a doação de 79 roupas estampadas por artistas plásticos da Coleção Rhodia - criadas como parte da estratégia publicitária para promover a marca Rhodia na década de $1960^{48}$ - e de sete peças produzidas na década de 1920 pelo costureiro Camilo Sabagh49. $\bigcirc$ museu possui ainda alguns trajes folclóricos do leste europeu e alguns figurinos do palhaço Piolin - Abelardo Pinto (1887-1973) -, mas não há maiores dados sobre quando teriam ocorrido tais doações ${ }^{50}$. Muito embora as doações tenham sido escassas, o desejo de formar a referida seção era tema constantemente alardeado por Bardi. Ele costumava referir-se a ela nos releases cedidos à imprensa, por ocasião dos eventos relacionados à moda sucedidos no museu no início da década de $1950^{51}$.

Em 1951, por exemplo, poucos dias antes da realização do desfile de "Costumes Antigos e Modernos", quando o museu recebeu o costureiro francês Marcel Rochas, então no Brasil para o lançamento de seu perfume, para uma palestra sobre "Elegância e Moda"52, além de anunciar o acontecimento, o release para a imprensa, certamente escrito por Bardi, informava que:

O Museu de Arte vem realizar com raro brilhantismo, para a alta sociedade paulistana um desfile de modas, já famoso nas crônicas elegantes e que constitui o marco inicial de uma série de atividades no campo da moda, inclusive a creação (sic) de uma Secção de Costumes, mostrando assim interesse que o Museu vem prestando aos assuntos ligados com as manifestações da moda e suas influências na cultura dos povos.(Conferência de Marcel Rochas no Museu de Arte) $)^{53}$

Em outros momentos, não titubeia em pedir doações de peças às famílias paulistanas, como no release feito por ocasião do desfile de "Costumes Antigos e Modernos", em que se explica:

Como os diretores do museu consideram a moda uma das mais importantes manifestações da arte, o sr. P. M. Bardi dirige às famílias paulistas um apelo no sentido de que considerem a possibilidade de doar costumes antigos ao Museu de Arte, muitos destes costumes estão guardados em armários quando na verdade poderiam, graças à boa vontade e colaboração destas famílias, enriquecer a coleção do Museu, concorrendo assim para o maior êxito dessa campanha que visa aumentar o nível cultural desta metrópole ${ }^{54}$

mesmo tipo de argumento é utilizado no artigo "Visão retrospectiva da moda desde a época feudal até hoje" do Diário de S. Paulo, de 07 de março
47. Cf. Ana Paula Crispi (2006, p. 171).

48. Sobre a Coleção Rhodia do MASP ver Maria Claudia Bonadio (2005) e Patrícia Sant'anna (2010).

49. Não é possível precisar a data de doação dessa coleção, a informação não constava na documentação relativa ao acervo de indumentária do MASP consultada em julho de 2012. Tais peças foram exibidas na exposição "Semana de 1922: antecedentes e consequências" ocorrida em 1972 no MASP como informa texto e fotografia veiculados em "MASP: Assis Chateaubriand, ano 30", cf. Pietro Maria Bardi (1977, p. 83) Porém, talvez tenham sido apenas emprestadas na ocasião, posto que nos documentos sobre a Seção de Costumes consta uma carta de Bardi à Agnes Sabbagh (esposa de Camilo), datada de 02 de dezembro de 1975, em que Bardi agradece a doação e diz "(...) estas peças constituem raro, se não único documento histórico de um tempo, no qual seu marido Camillo foi sem dúvida o grande personagem da alta costura".

50. Levando em conta que Piolin faleceu em 1973, é possível supor que a doação de seus figurinos seja posterior a essa data.

51. Em razão de sua larga experiência como jornalista, ao menos nos materiais levantados para essa pesquisa, é possível afirmar que era Bardi quem produzia os releases acerca dos eventos de moda realizados no museu - é bem provável que fizesse isso também para outras exposições ou eventos não relacionados à moda. Os textos não eram assinados, mas o tom da escrita, os conteúdos e a profundidade do conhecimento sobre os temas permitem crer na autoria de Bardi - mesmo 
na época em que atuava como jornalista na Itália nem sempre assinava seus textos.

52. Nos documentos relativos à palestra de Marcel Rochas no museu Caixa 3.1, Pasta 15 (Biblioteca e Centro de Documentação do MASP) -, há um recorte de jornal sem data denominado "Elegância e moda", mas provavelmente veiculado em 27 de março de 1951 (dia da palestra), que informa que Rochas estava no Brasil a convite dos Diários Associados.

53. Caixa 3.1, Pasta 15, documento 5 (Biblioteca e Centro de Documentação do MASP, 1951)

54. Desfile Dior, Caixa 4 , Pasta 22, documento 32 (Biblioteca e Centro de Documentação do MASP, 1951).

55. Ver Thornstein Veblen (2003, apud Ana Marta Gonzales, 2008).

56. Além do livro de James Laver (1949), muitos outros sobre moda compunham a biblioteca de Pietro Maria Bardi, dentre os quais: Blum, André. Histoire $d u$ costume. Paris: Hachette, 1928; Grand-Carteret, John, Gustave Girrane, Fernand Fan. La Femme en culotte. Ernest Flammarion, 1899; Colas, René. Bibliographie générale du costume et de la mode: Hacker Art Books, 1969; Haweis, Mary Eliza Joy. The art of beauty. Harper, 1878; Leclerc, Henri. Mademoiselle Bertin. Ministre dês modes La Reine Marie-Antoinette, Paris, MDCCCCXI (1811); Leloir, Maurice. Dictionnaire du costume et de ses accessoires: des armes et des étoffes, des origines à nos jours. Gründ, 1951;Ozzola, Leandro. II vestuario italiano del 1500 al 1550. Casa editrice Fratelli Palombi, MCMXL de 1951, quando, além de pedir doações, explana sobre as origens e importância da moda:

(...) A moda é uma das atividades importantes no campo da arte, e ainda que com suas épocas passageiras e variáveis, está ligada com recíprocas influências que traz a moda na vida do homem. (...) O vestido é para o corpo como o estilo é para uma época. Por outro lado, deve-se ressaltar que um belo traje vale tanto quando uma boa pintura. A moda é sempre a conseqüência de um modo de pensar e de viver (...). A moda é uma atividade antiga e acompanha a educação do homem nas diversas fases do desenvolvimento econômico. A moda é um fenômeno próprio das cidades onde é mais fácil o espírito da emulação, a observação das atitudes alheias.

trecho acima permite afirmar que Bardi compreende a moda como parte da visualidade de determinado período. Em seu entender, não é possível separar a moda da arte, posto que ambas estariam diretamente relacionadas e expressariam, em suas formas, certo "espírito do tempo", ideia bastante próxima daquelas expressas por James Laver (1899-1975) - então curador da seção de \|lustrações, Desenhos e Pinturas do museu inglês Victoria \& Albert - em Style in Costume, publicado na Inglaterra em 1949 e pertencente à coleção de livros sobre moda de P. M. Bardi e Lina Bo. A última frase desse mesmo trecho resume, de forma muito concisa, um dos principais argumentos utilizados por Thornstein Veblen (1857-1929) em The Economic Theory of Women's Dress, no qual explica que a moda seria uma manifestação mais comum nas cidades, exatamente porque a proximidade entre as pessoas propiciaria a emulação, por sua vez, fundamental para a propagação das modas. ${ }^{55}$

De modo geral, o que os textos de Bardi acerca da moda evidenciam é que o seu desejo de formar uma seção de costumes no museu se encontrava embasado em uma série de leituras teóricas sobre o tema ${ }^{56}$

Entretanto, apesar de toda essa explanação teórica sobre a importância da moda, os apelos de Bardi no tocante às doações para a Seção de Costumes não foram correspondidos. Os documentos que registram as doações e a circulação das peças de indumentária do MASP mostram que as doações de particulares só ocorreram a partir da década de 1980, intensificando-se apenas a partir do novo milênio. Em 1985, a senhora Zilda Mion doou alguns chapéus e, em 2003, foram registradas as seguintes doações: um vestido desenhado pela costureira francesa Jeanne Lanvin (1867-1946) na década de 1930, cedido por Patrícia Raia; vestidos e acessórios das décadas de 1930-1950 de Elizabeth Amaral de Barros; e um vestido dos anos 1930, cedido por Anita Cevidalle Salmoni.

No início dos anos 1950, ao contrário do que se imaginava, Bardi não conseguiu dar fôlego à Seção de Costumes do museu, mas a ideia aparentemente nunca foi abandonada. Em carta enviada ao sr. Ariel Chaves do shopping center carioca Fashion Mall - que realizaria uma exposição com algumas peças do acervo do MASP -, em 07 de março de 1983, Bardi explica: "Como o senhor deve imaginar estes vestidos da coleção Rhodia e alguns outros mais antigos que 
o museu possui deveriam constituir o núcleo de um museu do traje brasileiro, que infelizmente ainda não foi possível formar".

Mesmo que as fontes presentes no MASP e algumas declarações de Bardi à imprensa tragam informações desencontradas, é plausível considerar que, ainda na década de 1980, ele pensava na possibilidade de instituir no MASP uma Seção de Costumes. Possivelmente, por isso, tenha recusado a doação do acervo de indumentária do museu à instituição de ensino Senai-Cetiqt (Centro de Tecnologia da Indústria Química e Têxtil) do Rio de Janeiro ${ }^{57}$. A sugestão da doação aconteceu pouco tempo após a realização da exposição no Fashion Mall, quando Alexandre Figueira Rodrigues do Senai-Cetiqt the enviou uma carta aventando a cessão do material àquela instituição, pois, segundo o mesmo, a escola estava formando um Museu do Tecido. Em resposta, Bardi diz que até poderia doar o acervo, mas apenas para uma "instituição consolidada e em pleno funcionamento", e, assim, preferia aguardar a instalação do referido museu e, se fosse o caso, retomar as negociações num futuro próximo.

Já em entrevista concedida ao Estado de S. Paulo, em 20 de maio de 1976, Bardi declarava "não quero ter uma seção de trajes no MASP, não é nossa função". No entanto, na mesma entrevista, explicava que possuía uma coleção de veludos e sedas dos séculos XVI, XVII e XVIII (provavelmente particular, pois tais objetos não constam da coleção do MASP) e que estaria disposto a doá-la. Prossegue dizendo que um museu do traje poderia existir a partir da doação das famílias paulistanas e cariocas, que supostamente possuíam ricos acervos em suas casas, e da junção do acervo de indumentária do MASP com os de outros museus. Conclui falando que se "alguém se interessasse pela ideia, que começasse a colecionar".

Apesar da declaração contraditória, o interesse de Bardi pelo tema pode ser verificado ainda em seus últimos anos no museu, através das seguintes ações: a organização da coleção de recortes acerca da publicação do livro de Gilda de Mello e Souza, $O$ espírito das roupas: A moda no século XIX, e a realização de duas exposições. A primeira feita em 1986, com roupas bordadas pela artista plástica Glaucia Amaral, e a segunda, denominada Traje - um objeto de arte?, realizada em 1987. Esta última reuniu peças elaboradas por diversos artistas plásticos nacionais e estrangeiros, o Costume de 2045 e algumas roupas do acervo de Lina Bo Bardi, uma das quais criada por Luiza e Roberto Sambonet para o desfile "Moda Brasileira", ocorrido no MASP em 1952 e do qual trataremos adiante $^{58}$.

\section{desfile Costumes Antigos e Modernos}

No dia $1^{\circ}$ de abril de 1951, a capa do caderno "Vida Social e Doméstica" do jornal Folha da Manhã trazia a seguinte manchete "Desfile de modas deste e de outros tempos: Esplendor da costura francesa na passarelle instalada no Museu de Arte". O evento havia ocorrido na terça-feira, 27 de março,
(1940) - XVIII; Panzini, Alfredo. La penultima moda, 1850-1930. Roma: Paolo Cremonese, 1930; Sousa, Alberto Augusto de. Otrajo popular em Portugal nos séculos XVIII e XX. 1924; Squillace, Fausto. $L a$ moda. Milano, Napoli, Palermo: Remo Sandron Editore, 1912; Rudofsky, Bernard. Are Clothes Modern?: an Essay on Contemporary Apparel. Chicago Paul Theobald, 1947; Von Boehn, Max, Loschek, Ingrid. Die mode. Bruckmann, 1925. Nesse levantamento parcial, é possível notar que a maior parte das obras da coleção de Bardi é anterior ao início da formação da Seção de Costumes, ou seja, é bastante provável que Bardi tenha lido, pelo menos, parte delas para embasar seus escritos e também sua proposta para a seção.

57. O Senai-Cetiqt teve origem em 1949 quando foi criada no Rio de Janeiro a Escola Técnica da Indústria Química e Têxtil, e, em 1980, tornou-se o Centro de Tecnologia da Indústria Química e Têxtil.

58. A exposição Traje. Um objeto de arte? ficou em cartaz no MASP entre 7 e 26 de julho e contou com maciça divulgação de Bardi que, além de preparar para a imprensa textos explicativos sobre o conceito de Wearable art, posou para fotos usando peças da exposição. $\mathrm{Na}$ sequência, a exposição seguiu para o Rio de Janeiro, onde foi exibida no Rio Design Center entre 18 e 30 de agosto. 
59. Não há em nenhuma das fontes consultadas informações exatas sobre a quantidade de peças apresentadas no desfile, mas, levando em conta as peças fotografadas, é possível supor que se tratasse de apenas uma parte da coleção.

60. A Union Française des Artes $d u$ Costume foi fundada em 1948 por diversos profissionais, sob a liderança do historiador François Boucher, com o intuito de formar um Museu do Costume. Esse objetivo seria atingido apenas em 1987, quando é fundado o Musée de la Mode et du Costume em Paris.

61. Dentre as modelos que vieram apresentar as peças de Christian Dior a mais famosa era Bettina ou Simone Micheline Bodin (nascida em 1925, a modelo agregou o sobrenome Graziani após o casamento). Começou a carreira em 1947 na Maison de Jacques Fath, que lhe deu o apelido Bettina. Também ficou conhecida por seu trabalho na Maison Givenchy na qual ingressou em 1952, sendo considerada uma das modelos mais fotografadas da década de 1960. Seu envolvimento com o Príncipe Aly Khan (19111960) colaborou para tornála uma modelo celebridade. Uma curiosidade a seu respeito é que já aposentada fez uma participação no filme brasileiro Bete Balanço (Dir. Lael Rodrigues, 1984, cor, 74 min.). Em 2010, o então Ministro da Cultura e das Comunicações da França, Frédéric Mitterrand (1947-) congratulou-a com o prêmio da Ordem Francesa das Artes e das Letras.

62. Na caixa de documentação relativa ao desfile, há uma lista das músicas que deveriam ser executadas durante seu desenrolar bem como a indicação da peça mas a escolha da divulgação da matéria, que ocupava quase toda a página (dividindo espaço apenas com dois anúncios na parte inferior), no domingo, dia de maior vendagem de jornais, indica que provavelmente, para esse órgão de imprensa, o desfile realizado no museu era um tema de merecido destaque.

As fotografias que ilustram a reportagem, além de mostrarem alguns dos vestidos apresentados no desfile, exibem imagens da plateia em seus trajes a rigor. As mulheres assistiram à apresentação em vestidos longos, envoltas por estolas de peles e adornadas com joias, já os homens trajavam smokings. A partir das legendas das fotos e textos da reportagem, sabe-se que compareceram ao evento o exgovernador de São Paulo Ademar de Barros e sua esposa, o brigadeiro Armando Ararigbóia, a senhora Irene Crespi, o industrial André Matarazzo, entre outros.

Enfim, toda a pompa para prestigiar o desfile, que foi dividido em três partes: Modas do Passado, na qual foram exibidas peças pertencentes ao acervo do Costume Institute do Metropolitan Museum of Art e da Union Française des Arts du Costume (UFAC) e produzidas nos séculos XVIII e XIX, bem como uma réplica de um traje do século XVI; Modas do Presente, que mostrava uma parte da coleção mais atual da Maison Dior; e as Modas do Futuro ${ }^{59}$, que exibia o já citado Costume de 2045 criado por Salvador Dalío0. Todas as peças foram apresentadas por quatro modelos de Christian Dior: Bettina, Sylvie, Sophie e Allabl.

desfile das roupas se fez na maior parte do tempo ao som de música clássica, que criava uma atmosfera associada à época de cada peça. $\bigcirc$ Costume de 2045 foi exibido ao som da sinfonia The Planets: Mars, the bringer of War de Gustave Holst, com ares de trilha sonora de filme de ficção científicab2.

$\bigcirc$ evento parece ter sido um sucesso. Uma plateia elegante lotou a Pinacoteca do Museu, enquanto outros, igualmente elegantes, ficaram de fora! Segundo dados publicados no Diário de S. Paulo de 18 de março de 1951 , faltando pouco mais de uma semana para sua realização, já não era possível encontrar ingressos à venda. Dois dias após a apresentação de São Paulo, o desfile foi também realizado no Golden Room do Copacabana Palace, no Rio de Janeiro, e, tal como havia se dado em São Paulo, o valor arrecadado na venda de ingressos foi destinado a obras sociais. $\bigcirc$ evento do Rio, informa a reportagem de Diário de S. Paulo de 29 de março de 1951, foi viabilizado pelas senhoras Darcy Vargas e Sarah Kubitscheck (1909-1996)63.

Nas várias reportagens publicadas e também nos releases que escrevia para a imprensa, Bardi frisava que a intenção do desfile era marcar o início da formação da Seção de Costumes no museu. Tal objetivo, entretanto, não foi pensado de maneira aleatória, ou seja, as roupas desfiladas no museu provavelmente foram escolhidas em razão de seu caráter simbólico, que permitia associar moda à arte.

As peças de séculos passados, já retiradas de circulação e pertencentes a acervos de instituições consolidadas, demonstram, de certa forma, que, apesar de aparentemente efêmera, a moda expressa através do vestuário pode se tornar um objeto de museu. Ideia bastante concordante com o pensamento da socióloga 
Diana Crane, para quem a moda tem mais chances de ser considerada uma forma de arte quando vira "passado"64. Ao virar passado, isto é, ao sair de moda, e, portanto, ao tornarem-se inadequadas ao uso, as roupas perderiam a utilidade critério que, segundo a mesma autora (2011) e também para Deyan Sudijc (2010), diretor do Design Museum de Londres, é dos mais relevantes na definição daquilo que pode ou não ser definido como arte ${ }^{65}$.

Ao preservarem modos de vestir, técnicas, tecidos, formas corporais e gostos de outrora, as roupas do passado se tornariam ainda objetos patrimoniais, bens a serem preservados inclusive por museus de arte, como frisava Bardi em texto para divulgar à imprensa o desfile e a formação da Seção de Costumes ${ }^{66}$.

Ao assumir o "Museu de Arte" a incumbência de lançar esse novo empreendimento num tom de elevado gosto, nada mais faz que dar uma demonstração viva desse interesse pela moda que todos os grandes museus modernos - como o Metropolitan de New York - vem ultimamente demonstrando ${ }^{67}$.

As peças exibidas no desfile foram emprestadas da UFAC e do Metropolitan Museum of Art, mas apenas o segundo é mencionado no material para imprensa ao qual tive acesso. Isso, possivelmente, se deve ao fato de o primeiro ser ainda, à época, uma instituição sem espaço para exibir sua coleção, portanto, pouco conhecida do grande público, enquanto o museu nova-iorquino já possuía uma seção de costumes com mais de 10 mil peças ${ }^{68}$. $\bigcirc$ que Bardi não menciona, entretanto, é que tal coleção (formada a partir de peças coletadas por três irmãs filantrópicas e duas figurinistas) só foi agregada ao Metropolitan poucos anos antes, em 1946, ou seja, embora robusto, tratava-se de um acervo de indumentária bastante recente ${ }^{69}$. $\bigcirc$ texto do diretor do Metropolitan também é excessivamente efusivo ao mencionar que "todos os grandes museus modernos" vinham se interessando por moda! De fato, naquele momento, alguns museus começavam a formar seções de indumentária e outros já tinham até mesmo coleções volumosas, mas, dentre estes, apenas o Metropolitan era dedicado à arte. As demais coleções estavam ou em museus de artes decorativas, como o Victoria \& Albert, na Inglaterra, e o Philadelphia Museum of Art (criado tendo o citado museu inglês como modelol, ou em museus históricos, como o Museu Nacional de Budapeste e o Museu Hermitage na então União Soviética.

$\bigcirc$ texto de Bardi contém alguns exageros (ou foi escrito em um momento de entusiamo), mas a documentação encontrada no MASP deixa claro que o museu nova-iorquino era seu modelo inspirador. Em carta enviada ao Metropolitan em 22 de dezembro 1950, ele apresenta o MASP e pergunta se poderiam emprestar algumas peças para um desfile que pretendia organizar em São Paulo. Solicita o envio de catálogos e mais informações sobre a experiência com a seção de costumes. Antes de finalizar a carta, Bardi, provavelmente como forma de explicitar aos colegas do museu americano seus objetivos em constituir uma seção de costumes em São Paulo, conclui explicando que a proposta do MASP era sempre colocar a arte em contato direto com a vida ${ }^{70}$ para qual cada uma serviria de trilha sonora: Hector Berlioz (1803-1869); Le Carnaval Romain (traje de 1830); Luigi Cherubini (1760-1842); Anacréon, ou L'amour fugitif (Overture) (traje século XIX); Charles Gounod (1818-1893); Mireille, 1852; Daniel Auber (1782-1871); Fra-Diavolo (traje de 1852); Emannuel Chabrier (1841-1894), Joyeuse Marche (traje de 1895); Emilio de'Cavaliere (1550-1602); Rappresentatione di Anima et di Corpo (traje de 1550 - figurino); Gustave Holst (1874-1934); The Planets: Mars, the bringer of War (Costume de 2045).

63. É provável que elas tenham cuidado apenas da estrutura e divulgação local do desfile, pois todas as peças apresentadas no evento foram trazidas ao Brasil a partir do contato realizado por P.M. Bardi com museus e instituições internacionais e com a ajuda de Paulo Franco, que cuidou do translado das peças, conforme evidenciam cartas, telegramas e outros documentos encontrados na Biblioteca e Centro de Documentação do MASP

64. Cf. Diana Crane (2001)

65. Ainda que objetos de design como roupas possam ganhar status de arte quando deixam de ser fabricados ou quando perdem a utilidade (segundo Deyan Sudijc, um objeto produzido em larga escala ganha certa aura na medida em que envelhece), os preços mais altos que esses objetos costumam atingir em leilões de arte são bastante distantes daqueles que quadros de artistas consagrados costumam alcançar. Ver Deyan Sudjic (2010)

66. Utilizo a expressão objetos patrimoniais no sentido de um bem para o 
qual "se inibe ou se limita sua condição de mercadoria: não pode ser vendido ou não pode sofrer alterações" (Ver José Reginaldo Gonçalves, 2007, p. 244), como um objeto que tirado de circulaçãonão só tem seu valor drenado, como traz para qualquer uso prático eventual a pecha de sacrilégio (Ulpiano Bezerra de Meneses, 2005, p. 25), ou ainda um bem destinado ao "usufruto de uma comunidade" (Ver Françoise Choay, 2000, p. 11).

67. Cf. Desfile Dior, Caixa 4, Pasta 29, Subpasta "Material para a imprensa" (1951)

68. Ver Lou Taylor (2004). Em outro texto Bardi diz "O Museu de Arte sente-se honrado em anunciar mais uma vez o próximo desfile de modas femininas. Tratase de uma iniciativa 'sui generis', pois nunca antes alguns dos trajes mais significativos da moda nos últimos duzentos anos puderam ser apresentados por manequins vivos, como vai acontecer agora. Estes trajes, valiosíssimos pertencem a Museus europeus e americanos, e nos foram gentilmente cedidos para abrilhantar e tornar inesquecível a nossa apresentação." Doc. 07 Material para a imprensa s/d e sem assinatura, Desfile de Costumes, Caixa 4,Pasta 23 (1951).

69. Sobre a história da formação do acervo do Metropolitan, ver Lou Taylor (2004).

70. Não foram encontradas no Centro de Documentação do MASP respostas às cartas de Bardi ao Metropolitan, mas certamente a instituição as respondeu, posto que as peças de seu acervo foram exibidas no desfile do MASP.
Já a opção de apresentar no desfile a coleção de Christian Dior provavelmente se justifica em razão do prestígio desfrutado pelo costureiro, considerado o mais famoso nome da alta-costura do período. Em 1949, uma pesquisa realizada pelo Instituto Gallup, na França, revelava que Dior era, à época, uma das cinco personalidades internacionais mais conhecidas ${ }^{71}$. Tal sucesso se explica por ter sido ele o criador do New Look em 1947, silhueta que iria predominar na moda pelo menos até meados da década seguinte ${ }^{72}$.

Tamanha popularidade se deve não só ao sucesso do New look - que já em meados de 1947 era copiado em todo o mundo ocidental -, mas também em razão da política agressiva de expansão da marca, que em 1949 possuía lojas e produtos licenciados (especialmente meias e perfumes) à venda em diversos países do Ocidente, além de uma fábrica em Nova York ${ }^{73}$.

De todo modo, a qualidade de seus produtos e o status alcançado por Dior permitem categorizá-lo como um artista-artesão, categoria que, para Diana Crane, reuniria os costureiros que prezam pelo esmero em seus trabalhos, e para os quais suas produções, apesar de artesanais, seriam peças de arte ${ }^{74}$. $O$ próprio Christian Dior entendia-se como um artista ${ }^{75}$. Portanto, apresentar algumas das peças de sua coleção no desfile do MASP era uma forma de mostrar ao público aquilo que havia de mais "artístico" na produção de moda de então. Soma-se a isso o fato de todo o desfile ter sido exibido por quatro das manequins da marca, as quais tinham expertise em apresentar roupas e posar para fotos ${ }^{76}$.

Se Bardi cuidava pessoalmente dos textos que divulgavam suas ações na imprensa, é muito provável que as fotos de divulgação do evento, em especial aquelas realizadas pelo fotógrafo oficial do museu, o alemão Peter Scheier (19081979), também contassem com sua "codireção". Boa parte das imagens era produzida de modo a "contaminar" as peças de roupas com o valor simbólico das obras de arte expostas no museu. Elas evidenciavam que o desfile havia acontecido na Pinacoteca do museu, ou seja, com a passarela no meio da sala de exposições, tendo ao fundo os quadros e esculturas que se misturavam às roupas. As fotografias eram tiradas fora da passarela, em cenas nas quais as modelos interagiam de forma extrovertida com as obras de arte ${ }^{77}$.

Em uma das fołos, por exemplo, a estátua da Deusa Higéia (século IV a.C.) fazia fundo para a manequim Alla, que exibia um vestido e uma echarpe esvoaçantes de Dior, em composição muito semelhante àquela usada alguns anos mais tarde em cena do filme Cinderela em Paris [Funny Face, Dir. Stanley Donen, 1956, 103 min, cor], protagonizado por Audrey Hepburn e com direção fotográfica de Richard Avedon, na qual a personagem principal desce as escadarias do Louvre com um vestido igualmente esvoaçante tendo a estátua da Vitória de Samotrácia ao fundo ${ }^{78}$ (Figuras 1 e 2). Vale mencionar que logo após seu lançamento, o filme se tornaria uma referência para a moda, não só por retratar o universo de uma revista de moda e da alta-costua, mas também pelas cenas que mostravam a produção das fotografias para a revista. A sintonia entre as imagens dirigidas pelo fotógrafo de moda Richard Avedon e Scheier/Bardi 
permite apontar para a sensibilidade e olhar aguçado dos últimos em relação ao universo da moda.

Para encerrar o desfile, o Costume de 2045, peça criada por Salvador Dalí, portanto, desenhada por um artista já consagrado, poderia ser tomada como uma obra de arte, ainda que fora dos suportes tradicionais. Essa indumentária poderia ser considerada ainda uma "roupa de artista", termo que comumente designa roupas criadas por artistas e que rejeitam a moda "oficial", recusam a lógica do mercado e têm como proposta uma antimoda utópica ${ }^{79}$.

Em resumo, mesmo que, para Bardi, a moda estivesse integrada ao universo da arte, para o público em geral tal associação não era tão evidente, assim o desfile seria cuidadosamente estruturado de forma a mostrar na passarela elementos que reforçassem a associação entre moda e arte.
71. Cf. Gilles Lipovetsky (1989).

72. New Look é o nome pelo qual ficou conhecida a silhueta proposta por Christian Dior em sua primeira coleção, lançada na primavera de 1947 , que deixava de lado as roupas mais sóbrias e ajustadas em vigor durante todo o período da Segunda Guerra Mundial. Tornou-se conhecida como New Look, quando a editora de moda da revista americana Harper's Bazaar chamou
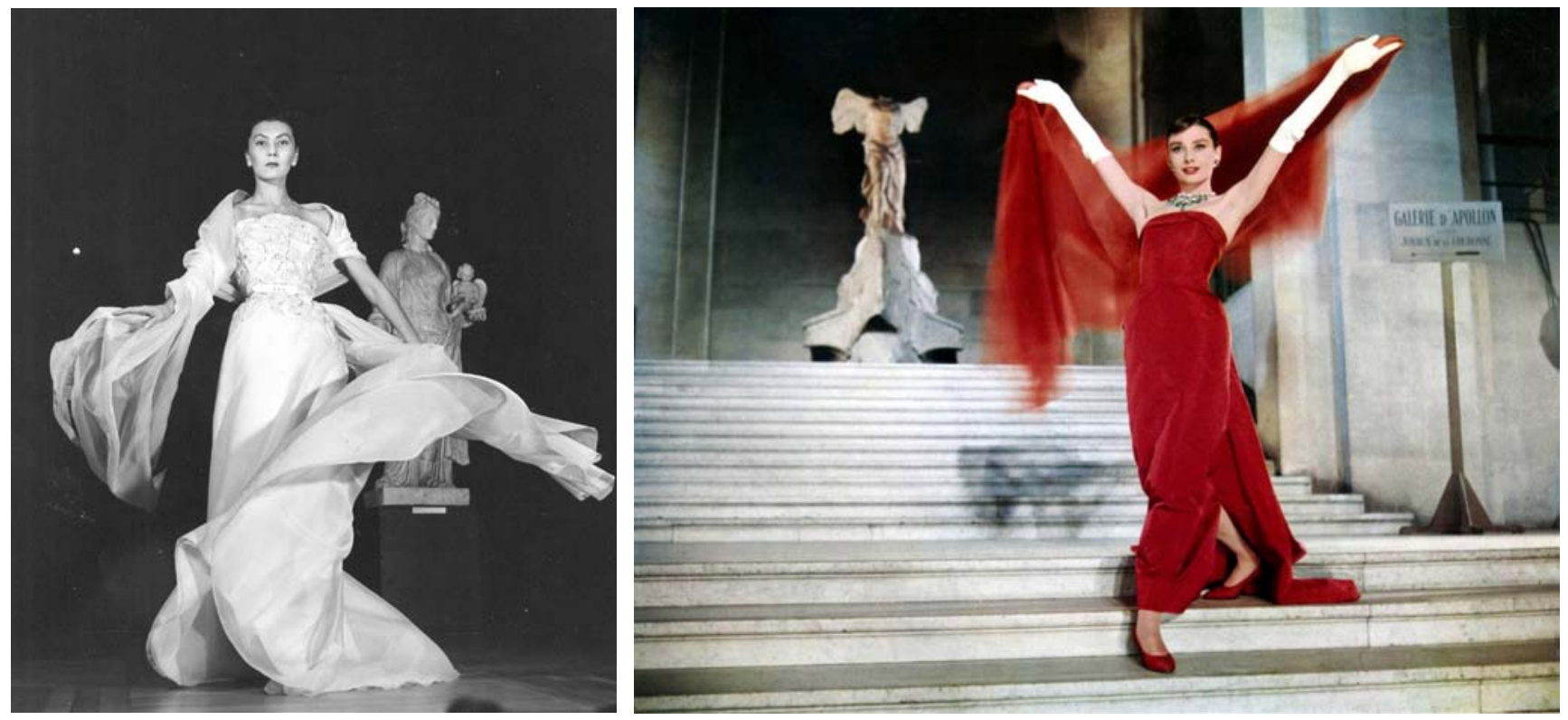

Figura 1: Alla, modelo de Christian Dior, desfilando Figura 2: Audrey Hepburn em cena do filme Cinderela em Paris [Funny Face, Dir. na passarela montada na pinacoteca do MASP, Stanley Donen, 1956, 103 min, cor]

1951. Instituto Moreira Salles.

A Coleção "Moda Brasileira"

Num de seus releases para a imprensa, provavelmente escrito após o desfile de "Costumes Antigos e Modernos", Bardi se mostrava eufórico ao afirmar que Paulo Franco iria realizar o desfile do próximo ano e que seria também responsável pela organização da "nova Seção de Costumes, que a exemplo dos mais importantes museus do mundo, o Museu de Arte está desenvolvendo"80.

Como anunciado, no ano seguinte, mais precisamente no dia 06 de novembro, o MASP voltaria a sediar um desfile de moda. Dessa vez, nada de roupas de museus estrangeiros ou costureiros famosos, apenas peças criadas nas oficinas assim uma das peças da coleção, o tailleur Bar que tinha saia rodada de comprimento médio (um pouco abaixo do joelho) e cintura acentuada (para obter-se a silhueta proposta era preciso recorrer às cintas elásticas). $\mathrm{O}$ nome acabou sendo empregado para denominar a silhueta em voga entre os anos de 1947 e meados da década de 1950. O traje era 
inspirado na silhueta do século XIX e foi visto com ressalvas por alguns críticos que o consideraram uma "tentativa inadequada $\mathrm{e}$ irresponsável de coibir a liberdade feminina", cf. Amy de La Haye e Valerie Endes (2003, p. 128).

73. Em 1949, existiam boutiques da marca Christian Dior espalhadas do MASP e inspiradas na fauna e flora, nas culturas indígena e afro-brasileira e em costumes populares. Já a parceria com Paulo Franco foi provavelmente desfeita, pois seu nome não aparece no programa do desfile nem em nenhum release ou texto publicado na imprensa. Nas fotos que registram o evento, Paulo Franco e sua esposa figuram apenas em uma pequena imagem publicada na revista Habitat. Fotografia não posada, em que aparece de costas, muito diferente do desfile do ano anterior, quando foi fotografado posando ao lado de Bardi, Lina, sua esposa e três modelos da Maison Christian Dior. Todos esses dados parecem, portanto, reforçar o possível rompimento da parceria entre Bardi e Franco. (Figuras 3 e 4)

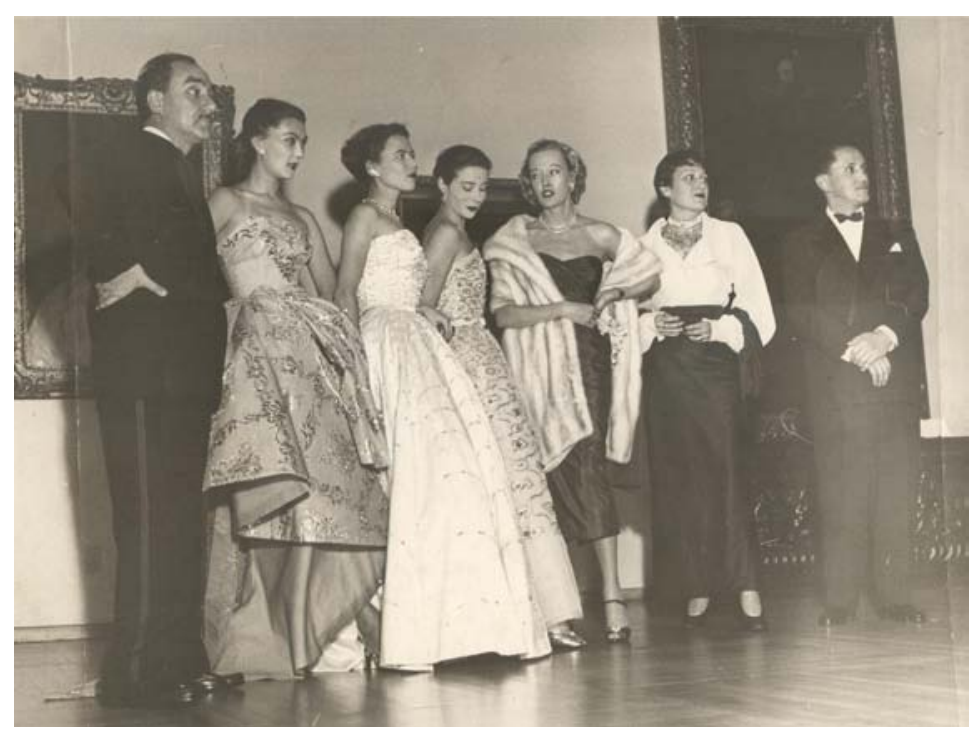

Figura 3: Da esquerda para a direita: Bardi, Alla, Sophie, Bettina, Sra. Paulo Franco, Lina e Paulo Franco. Biblioteca e Centro de Documentação do MASP.

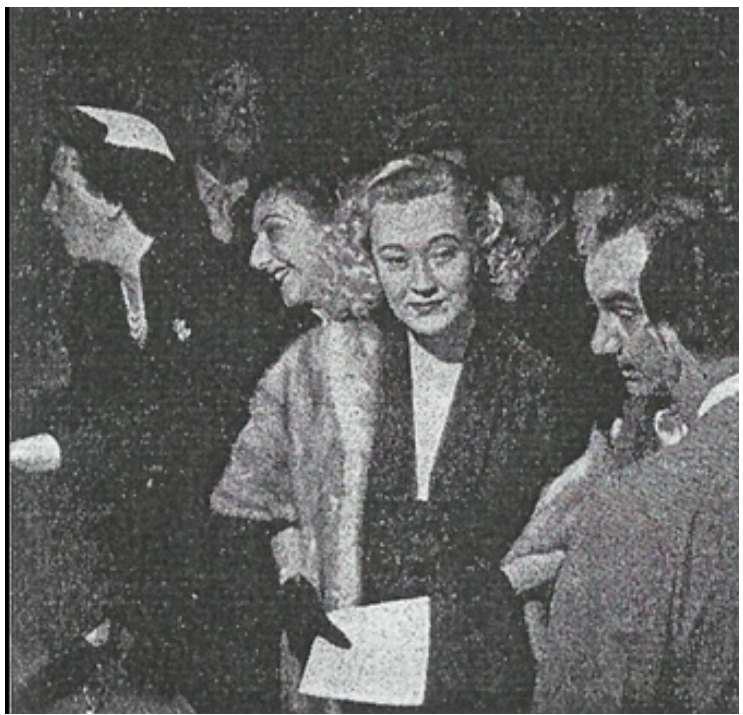

Figura 4: Ao centro sra. Paulo Franco, Bardi e Paulo Franco de costas. Habitat..n. 9, out.-nov. 1952. Biblioteca e Centro de Documentação do MASP. por 17 países, inclusive o Brasil, cf. Alexandra Palmer (2009). Sobre a loja brasileira há poucas informações, mas é possível que tenha sido ligada a Casa Vogue e, portanto, administrada por Paulo Franco.

74. Ver Diana Crane (2011). 75. Ver Ilya Parkins (2012).

76. Apesar de Bardi mencionar na carta enviada ao Metropolitan em 22 de setembro de 1950 que Dior viria ao Brasil para o desfile, tal visita provavelmente não ocorreu, pois as reportagens
Ademais, os novos objetivos de Bardi para as ações do museu em relação à moda justificariam a quebra da parceria com o comerciante. Bardi queria agora "criar uma moda brasileira", uma moda feita em grande parte com matérias-primas e estampas que remetessem a uma visualidade brasileira. Para Franco, que comandava em São Paulo uma bem-sucedida loja de moda de luxo e que tinha como característica vender no Brasil peças de alta-costura ou produzir aqui peças que seguissem de perto as linhas ditadas internacionalmente, tais objetivos pareciam descabidos. Mas Bardi não era um homem de projetos modestos $^{81}$.

desfile "Moda Brasileira", realizado no MASP em 1952, apresentou uma coleção constituída de 50 peças, cujos tecidos, estampas e modelos foram todos projetados por designers e artistas que atuavam no IAC e parcialmente produzidos nas oficinas ali instaladas. Outra parte foi produzida com o apoio de indústrias têxteis como a Ribeiro Industrial S.A, a Industil S.A, a Lutfalla S.A. e Santa 
Constância. Para mostrar as roupas, modelos brasileiras foram treinadas na Escola de modelos que Bardi instalou no MASP82.

Esse evento não contou com a pompa do desfile anterior. Os convites não foram vendidos, mas retirados gratuitamente na primeira sobreloja do Mappin, onde as roupas foram comercializadas após a exibição no museu, como informava o anúncio veiculado na Folha da Manhã no caderno "Assuntos Gerais" do dia 05 de novembro ${ }^{83}$. $\bigcirc$ horário do desfile, 17 horas, exigiu que peles e longos fossem substituídos por tailleurs acompanhados de chapéus. Se o evento do ano anterior havia sido um sucesso, esse, ao tratar da moda brasileira, prometia gerar ainda mais curiosidade entre os espectadores. Talvez tenha sido esse mesmo o argumento usado por Bardi para obter o apoio de Chateaubriand na divulgação do evento, que foi transmitido pela TV Tupi no dia 07 de novembro ${ }^{84}$.

$\bigcirc$ evento parecer ter sido considerado uma grande atração pela imprensa, pois, novamente na cobertura da Folha da Manhã, o desfile ocorrido numa quintafeira foi divulgado no jornal de domingo. Na reportagem, senhoras da sociedade elogiavam a iniciativa. A senhora Dana Mendonça, por exemplo, lembrava que o espanhol Cristóbal Balenciaga (1 895-1972)85, tido então por muitos como o maior "costureiro francês", "era a prova de que raças, realidades geográficas e históricas podem incorporar-se à moda". E prossegue argumentando que

A retrosaria, os boleros, as rendas que lembram mantilhas de "majas" e tanta coisa mais fazem uma permanência constante da Espanha na moda de Paris. A moda brasileira que está sendo ideada por verdadeiros artistas pode inclusive ser exportada, como foram o samba e o baião ${ }^{86}$.

Outras expectadoras, como a senhora Elza Weil, explicavam que, a partir do referido desfile, seria possível ter no Brasil uma elegância adequada ao clima e aos hábitos locais.

Já a reportagem "Traçou novos rumos para a elegância feminina o desfile de modelos de inspiração brasileira" do Diário da Noite ${ }^{87}$, pertencente ao grupo dos Diários Associados, era ainda mais ufanista e dizia que o desfile marcou o início de uma "nova era da moda brasileira" ao se constituir na primeira mostra de modelos "realmente nacionais". As senhoras da plateia entrevistadas para a reportagem se mostraram tão animadas com a iniciativa quanto aquelas que falaram à Folha da Manhã.

Nas fotos divulgadas nas referidas matérias, as modelos brasileiras aparecem bastante desenvoltas na passarela. Mas, nas fotos posadas, mesmo a habilidade de Peter Scheier (provável autor das fotos) parece não ter sido suficiente para fazê-las interagir de forma mais descontraída com as obras expostas no museu. Em tais imagens, ao contrário do que havia acontecido com as modelos francesas, as brasileiras aparentavam estar desconfortáveis, como se fossem coadjuvantes diante dos quadros e esculturas ${ }^{88}$. Essa diferença de comportamento pode ser observada nas fotos abaixo. Na primeira, a manequim francesa coloca o pé sobre o pedestal da escultura de Victor Brecheret, olha para veiculadas na imprensa não citam nem mostram fotos do costureiro no Brasil, ou seja, apenas suas manequins e a coleção foram apresentadas no país.

76. Segundo Helouise Costa, as fotos do desfile divulgadas em O Cruzeiro foram realizadas também por Henri Ballot (19211997). Entretanto, é possível supor que Ballot teria feito as fotos do desfile e Peter Scheier as fotos posadas, pois, no livro As origens do fotojornalismo, há duas páginas ilustradas apenas com fotos do fotógrafo alemão, todas fora da passarela e com as modelos posando junto às obras de arte. Ver Helouise Costa (2012).

77. A importância do convívio com o casal Lina e PM. Bardi para a maturação do trabalho que Peter Scheier desenvolve no Brasil é tratada por Anat Falbel (2007).

78. Cf. Radu Stern (2004). O termo "roupa de artista" se aplicaria à roupa em questão, posto que se tratava de uma peça "fora de moda" e que propunha uma visão utópica da "mulher do futuro", porém, o termo não necessariamente pode ser usado para designar outras incursões (mais comerciais) de Salvador Dalí no campo do design de moda. Na década de 1930, desenhou alguns croquis para a costureira italiana Elsa Schiaparelli (1890-1973), como, por exemplo, o vestido esqueleto de 1938. Atuou também ao lado do designer de joias Fulco di Verduga (1898-1978) no início dos anos 1940 e, em 1949, assinou contrato para produzir algumas joias em parceria com Carlos B. Alemany e com o magnata dos transportes Eric Ertman, como resultado criou o "Brinco Telefone" e o "Broche Lábios de Rubi", entre outros. Ver. Ghislaine Wood (2007) 
80. Desfile de Costumes, Caixa 4, Pasta 23 (1951).

81. Neste ponto, é possível aventar que, no ano anterior, ao trazer para o Brasil peças da marca Christian a câmera e sorri, enquanto, na segunda, as manequins brasileiras, sentadas ao pé de uma escultura, riem de modo mais envergonhando e sem encarar a câmera (Figuras. 5 e 6). Tais imagens fazem supor que, apesar de bem preparadas para se apresentarem na passarela, as modelos não tiveram um treinamento para posar para fotografias.

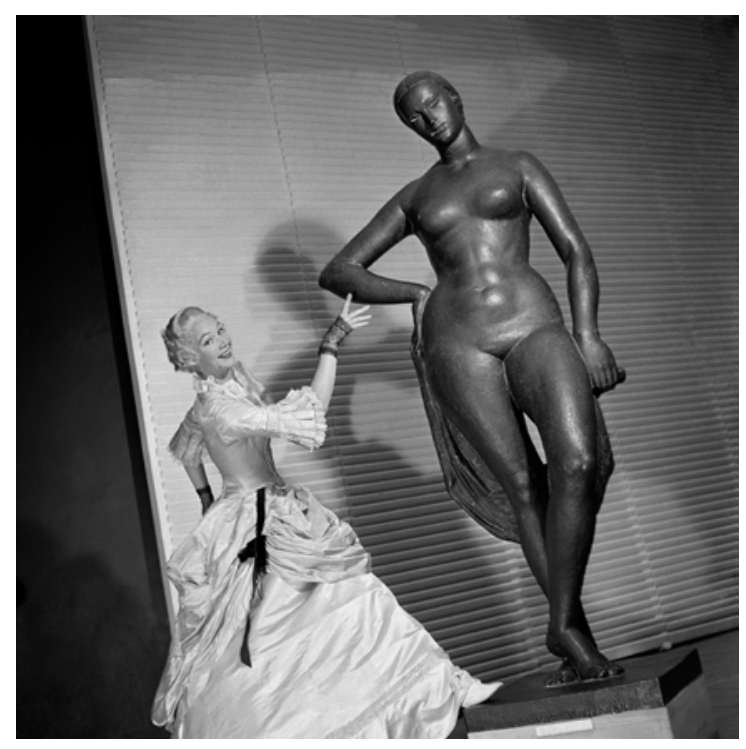

Figura 5: Sophie, modelo de Christian Dior trajando costume do século XVIII em foto de 1951 diante de um "Nu", de Victor Brecheret. Foto de Peter Scheier. Biblioteca e Centro de Documentação do MASP/Instituto Moreira Salles.

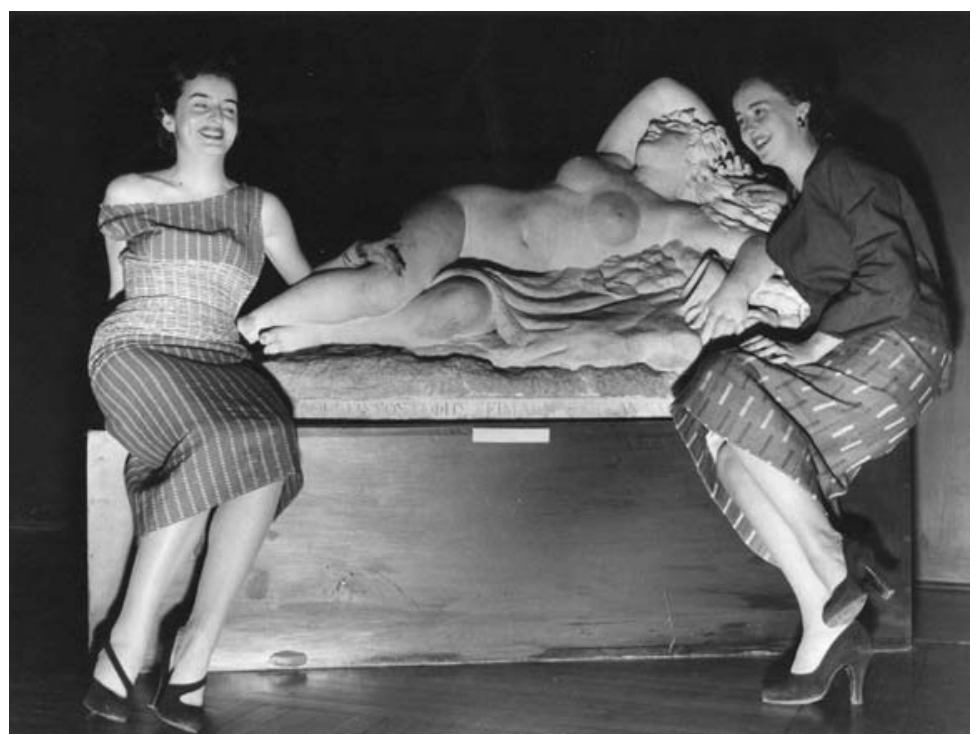

Figura 6: Duas modelos brasileiras com trajes elaborados nas oficinas do MASP para a Coleção "Moda Brasileira" (1952) posando diante da "Bacante adormecida" de Valério Vilarealle, 1833. Foto de Peter Scheier. Biblioteca e Centro de Documentação do MASP/Instituto Moreira Salles.
Dior, Bardi tenha atuado dentro da premissa do Sindicato Nacional Fascista de Belas-Artes - que pautava, aliás, as exposições que organizou para a Galeria de Arte de Roma -, o qual entendia que levar para a Itália exposições de artistas estrangeiros já estabelecidos colaboraria no desenvolvimento do campo da arte italiana.

82. No período, o campo de atuação para as modelos era bastante restrito, consistia basicamente em desfiles realizados em lojas de moda de luxo ou grandes magazines, posto que a produção editorial de moda ainda era incipiente no país, Ver Maria Claudia Bonadio (2004). Nesses
Talvez tenha sido por isso que os editores da Folha da Manhã e do Diário da Noite tenham preferido divulgar, em suas matérias, apenas as fotos das modelos nas passarelas. Exceção era a foto exibida no final da matéria do Diário da Noite, que mostrava passantes em frente à vitrine do Mappin, que exibia as peças da Coleção "Moda Brasileira".

Como era de praxe nos anúncios do Mappin, aquele veiculado na mesma página da reportagem "Lançamentos da Moda Brasileira", publicada em 09 de novembro de 1952 na Folha da Manhã, trazia os valores de alguns dos vestidos ali exibidos, que variavam de 1.800,00 a 5.200,00 cruzeiros.

Segundo Bardi, os preços dos produtos da Coleção "Moda Brasileira" eram acessíveis e sua venda teria sido um sucesso ${ }^{89}$. Entretanto, na mesma entrevista em que comenta que as vendas foram bem-sucedidas, ao recordar o desfile, afirma que este foi um escândalo e que a iniciativa teria sido uma "pedra jogada na água que provocou algumas ondulações na superfície e depois desapareceu".

Opinião semelhante será propagada em outras entrevistas do diretor do museu. Aliás, em 1982, em entrevista concedida à revista Jeans e Sportwear, 
relatou que, apesar da boa acolhida do Mappin, que teria dedicado todas as suas vitrines à coleção, a iniciativa foi vista como "uma piada e alguns pensaram 'vem aqui um italiano e lança a moda brasileira'. Só depois é que entendi a risada do saudoso Paulo Franco quando the falei do meu projeto de lançála. Mas ele não quis desalentar a minha ingenuidade (...)"90.

A despeito da ausência de dados sobre a venda das peças, a descontinuidade do projeto e as declarações posteriores de Bardi indicam que a coleção não caiu no gosto do público.

A conversão dos preços listados no catálogo para o real, bem como a comparação aproximada dos valores das roupas com o salário mínimo pago à época permitem aventar que as elites eram o público-alvo da coleção, para as quais abandonar os códigos de elegância já estabelecidos era ainda mais complicado. Dentre as peças anunciadas, as mais baratas custavam Cr $\$ 1.500,00$ ao passo que o salário mínimo estabelecido em janeiro de 1952 era de Cr\$ 1.190,9091. Na conversão para o real, a peça mais barata anunciada (Cr\$ $1.500,00)$ sairia hoje por 3.600,00 reais e a mais cara $(\mathrm{Cr} \$ 9800,00)$ por 29.400,00 reais $^{92}$.

No que diz respeito à imprensa, ainda que esta não tenha emitido opinião negativa sobre o assunto, tratou-o apenas como um episódio digno de nota, sem, entretanto, dar desdobramento ao tema da moda brasileira em outras reportagens. Em termos de moda, aquilo que cai no gosto do público recebe frequente atenção da imprensa. $\bigcirc$ que não foi o caso. Como bem disse Bardi, os efeitos da iniciativa parecem não ter causado grandes ondas.

\section{problema remoto da moda}

Talvez por pressentir que apresentar no museu uma moda inspirada em temas e confeccionada com materiais locais pudesse causar polêmica, ou simplesmente porque tivesse grande entusiasmo em relação ao projeto, nos meses que antecederam o desfile e logo após sua realização, Bardi reativaria seu lado jornalista publicando na Habitat alguns textos que explicam a importância da iniciativa.

No número 07 da Habitat: revista das Artes no Brasil, o texto "A moda no Brasil", veiculado alguns meses antes do desfile, ocorrido no mês de novembro - não assinado, mas provavelmente escrito por Bardi, uma vez que se coaduna com grande parte das ideias acerca do papel do museu expressas em "Um museu fora dos limites" -, resume as ações da instituição no campo do design e explica, em seus parágrafos finais, que o museu pretendia ingressar no campo da moda a partir da

criação de uma escola para costureiros e artesãos que se dedicam aos problemas colaterais da moda. (...) cogita-se da criação, no Museu, de um centro de atividades que possa dar origem, algum dia a uma variedade de moda de inspiração brasileira liberta de dependências ${ }^{93}$. desfiles, eram as vendedoras e algumas clientes que comumente atuavam como manequins Nesse cenário inexistiam escolas de modelos, daí a necessidade de o MASP criar o curso para manequins quando do desfile de 1952.

83. A parceria entre o MASP e o Mappin não se ateve à comercialização das peças produzidas para o desfile "Moda Brasileira", pois, segundo Ethel Leon, Alexandre Wollner teria realizado algumas vitrines para o MASP no período em que estudou no IAC.

84. Apesar de sua boa relação com Bardi, o entendimento de Chateaubriand no que diz r e s p e i t o a o desenvolvimento da moda brasileira era bastante diverso daquele de Bardi, sua opinião se aproximava mais da de Paulo Franco, como se observa nas ações que realiza também em 1952. Naquele ano, com vistas a promover o algodão brasileiro de fibra longa, traz ao Brasil o costureiro francês Jacques Fath que cria padronagens para a Bangu Têxtil e realiza desfiles de vestidos criados por ele e confeccionados com o algodão Bangu com padronagens igualmente elaboradas pelo costureiro e apresentados por suas manequins. Ou seja, presumivelmente, em sua opinião, a melhor maneira de agregar valor à moda brasileira seria associá-la à alta-costura francesa. Sobre esse tema, ver Maria Claudia Bonadio (2013).

85. Balenciaga foi um dos nomes mais importantes da alta-costura entre o final da Segunda Guerra e meados da década de 1960 .

86. Cf. Folba da Manhã (09/11/1952, p. 5). 
87. Cf. Diário da Noite (10/11/1952, p. 11).

88. Biblioteca e Centro de Documentação do MASP.

89. Veja (29/03/1972).

90. Jeans e Sportwear (1982, p. 25).

91. Valor do salário mínimo publicado no jornal $O$ Estado de S. Paulo em 03 de fevereiro de 1952, p. 21.

92. Para a conversão aproximada dos valores foi utilizado o conversor de moedas disponível no site do Acervo do jornal $O$ Estado de S. Paulo, acessível em: <http://acervo.estadao. com.br/>. Fala-se conversão aproximada, pois o site em questão informa que tal cálculo é estimado e não deve ser utilizado em conversões oficiais.

93. Habitat (abr.-jul., 1952, s. p.).

94. Pietro Maria Bardi (1978, p. 42).

95. Provavelmente em referência à Corporação Nacional de Moda Italiana criado em 1935.

96. Habitat (abril-julho, 1952, s. p.).

97. Ver Pietro Maria Bardi (1952).

98.Ver Silvana Rubino e Marina Grinover (2009).

99. Habitat (outubronovembro, 1952, s.p.).
O "centro de atividades" seria mencionado mais uma vez em nota publicada na Folha da Manhã em 01 de novembro de 1952, a qual informa que o desfile de moda brasileira teve todos os seus trajes confeccionados pelo Centro de Estudos sobre Moda, que oferecia "cursos de manequins, desenho de padrões para tecidos, tecelagem, oficina de costura, etc." ${ }^{\prime 94}$.

O texto prossegue relatando que processo semelhante ocorrera na ltália, nos anos anteriores a Segunda Guerra, quando foi criado, em Turim, o Departamento da Moda Italiana, do qual tratarei adiante. A iniciativa teria sido recebida com ironia pelos observadores ${ }^{95}$, entretanto, passados alguns anos, conforme o texto esclarece, a moda italiana ganhou projeção e estabeleceu identidade própria que "ao nosso ver, pode perfeitamente figurar ao lado da moda francesa"90.

A questão é retomada no artigo "Problema remoto da moda" veiculado na nona edição da revista97, também sem assinatura e novamente um provável texto de Bardi ou escrito a quatro mãos com Lina. Essa presumível autoria a quatro mãos é evidenciada pela passagem a seguir, na qual se propõe que a originalidade da moda brasileira poderia resultar da apropriação da produção artesanal. Ora, o estudo do artesanato e a integração deste ao design era um dos pontos cruciais na obra arquitetônica e produção textual de Lina Bo Bardi. Além da proximidade com o trabalho de Lina, o texto apresentava o que seria o "ponto de vista" oficial do museu, daí os indícios de haver sido uma produção do casal Bardi98.

A história da moda importada de fora, infelizmente, uma exigência de países nos quais o artezanato (sic) não tinha se desenvolvido por falta de tradição cultural autóctone e por falta de condições artísticas originais, capazes de oferecer ao público formas belas e apropriadas. Entretanto, o que os mais inteligentes compreenderam é o seguinte: a moda é relativa às condições específicas de cultura, clima, geografia e ainda, de estrutura anatômica de elementos somáticos e mesmo cor e pele.

Nos parágrafos que se seguem, a ideia da necessidade da criação de uma moda com acento local é novamente frisada em passagens que propõem que a moda produzida no país deveria ser

autêntica, correspondente ao "tipo brasileiro" (...) uma moda apropriada às condições específicas da produção brasileira e da economia em geral (...). Uma moda conveniente à nossa paisagem, tão rica de inspirações, conveniente ainda aos modos de viver, de trabalhar, de se divertir (...).

Antes de encerrar, ressalta-se que a tentativa da criação de uma "moda brasileira" foi efetuada pelo Museu de Arte de São Paulo (MASP), "instituição que considera o campo da moda um campo verdadeiramente artístico" 99.

No mesmo número da revista, o clima, o folclore local e a paisagem são novamente mencionados como peculiaridades a serem respeitadas na criação de um vestir brasileiro. A ideia é defendida no texto "Uma moda brasileira", de autoria da também italiana Luisa Sambonet (esposa de Roberto Sambonet), 
responsável pela criação de algumas peças da coleção exibida no desfile "Moda Brasileira" 100. Trabalharam ainda nas diversas fases dessa coleção os seguintes profissionais: a alemã Klara Hartoch, responsável pelo ateliê de tecelagem do museu, que criou tramas têxteis inspiradas em motivos da cerâmica marajoara e palhas trançadas inspiradas na cestaria indígena; o argentino Carybé (19111997), que criou estampas inspiradas no candomblé; o italiano Roberto Sambonet (1924-1995), que desenhou a maior parte da coleção, criando igualmente estampas de inspiração marajoara e em antúrios (flor típica dos ambientes tropicais), e foi o responsável pelo projeto gráfico dos convites e peças gráficas do evento, além do paisagista brasileiro Roberto Burle Marx (1909-1994), que também projetou estampas para a coleção ${ }^{101}$.

nacionalismo na moda, ou seja, a valorização da produção nacional em detrimento da moda unicamente calcada nas linhas propostas pelos costureiros parisienses, presente nas ações e pensamentos de Bardi, é possivelmente uma transposição para o Brasil de algumas das ideias fascistas em relação à moda. Na década de 1930, Mussolini passou a incentivar o desenvolvimento da moda italiana e, para tanto, propiciou, em 1932, uma grande exposição da moda nacional denominada Ente autonomo per Mostra permanente Nazionale della Moda em Turim, que daria origem à Corporação Nacional de Moda Italiana (Ente Nazionale Della Moda), criada em 1935 com o objetivo de "estimular e promover o consumo da moda italiana"102.

No "plano ideológico do fascismo, a moda foi identificada como um terreno privilegiado que daria uma contribuição significativa para a realização do senso de nação"103. Assim, entre outras ações, o grupo iria: a) criar o selo "Made in Italy", cuja função era garantir que a roupa fosse fabricada no país; b) estimular a "italianização" de termos e nomes franceses associados à moda, os quais passaram a ser divulgados a partir da publicação, em 1936, do Commentario Dizionario Italiano Della Moda de Cesare Meano; c) regular as informações veiculadas nas revistas de moda, nas quais os editores até poderiam publicar silhuetas propostas pela moda de Paris, mas teriam de omitir o nome do costureiro ${ }^{104}$; d) "construir uma indústria têxtil capaz de competir no mercado estrangeiro"; e) "criar um estilo distinto reconhecível como italiano e admirado internacionalmente como tal" 105 .

Ainda que tenham sido recebidas com ressalvas pelos designers e costureiros, tais iniciativas colaboraram para a criação de um sentimento nacionalista em relação à moda italiana. A partir delas, "os tecidos italianos começaram a se destacar" e "sua revitalização se deu pelo uso de elementos estéticos que ressaltam suas características nacionais, como fibra mais rústica de algodão e linho", entre outros ${ }^{106}$.

Eugenia Paulicelli, ao tratar das políticas voltadas para a moda na ltália fascista e, em especial, do Commentário dizionario ${ }^{107}$, evoca Roland Barthes para lembrar que, na moda, os sentidos (ou significados, para usar o vocabulário barthesiano) de uma peça de roupa são, em muito, formulados pelo texto, ou seja,
100. Ver Luisa Sambonet (1952). Nos textos veiculados à época do lançamento da Coleção "Moda Brasileira" não há menções à participação de Luisa Sambonet na criação de peças, mas, anos mais tarde, em 1987, quando ocorre a exposição "Traje. Um objeto de Arte?" no MASP, o catálogo da exposição informa que a peça número 12 é uma criação de Luisa e Roberto Sambonet e que se trata da interpretação de um traje indígena da fronteira do Paraguai. A descrição corresponde ao traje número 50 do catálogo do desfile "Moda Brasileira" denominado Fronteira, cujo texto informa ser um "modelo inspirado nos trajes das índias da fronteira do Paraguai”. Além disso, na dissertação de mestrado de Ethel Leon (2006), a pesquisadora se refere à Luisa como idealizadora da referida coleção, dado que talvez tenha levantado junto aos ex-alunos do IAC que entrevistou. Portanto, é muito provável que tenham criado algumas peças em parceria, mas apenas Roberto tenha levado os créditos.

101. Há poucas informações disponíveis a respeito de Klara Hartoch. Em sua dissertação sobre o IAC, Ethel Leon (2006) relata que alguns dos exprofissionais e ex-alunos do IAC que entrevistou relataram que Bardi sempre a apresentava como exaluna da designer têxtil Anni Albers (1899-1994) na Bauhaus.

102. Cf. Angélica Adverse (2011, p. 147).

103. Cf. Eugenia Paulicelli (2004, p. 27).

104. http://www.vice.com/ $\mathrm{read} /$ fashions-forgottenfascists e http://www. vogue.it/en/encyclo/ fashion/t/turin-and-fashion, 
Italian Haute Couture: First attempts of emancipation from France (1906-1959) Luca lo Sicco. http://www. inter-disciplinary.net/wpcontent/uploads/2009/08/ Lo-S i c co-pa per.pdf. Acessado em: 12 fev. 2014.

105. Cf. Eugenia Paulicelli (2004, p. 27).

106. Cf. Angélica Adverse (2012, p.147).

107. Ainda segundo Eugenia Paulicelli, um dos resultados da publicação do texto de Meano foi a implementação de uma lista, veiculada pelas revistas de moda, com o equivalente em italiano dos termos estrangeiros, cujo uso passa, então, a ser obrigatório, ver Eugenia Paulicelli (2004).

108. Ver Roland Barthes (2005).

109. Cf. Rafael Cardoso (2004, p. 135). A referência à Bauhaus e também ao Instituto de Design de Chicago como modelos a serem seguidos aparecem em vários escritos de Bardi, sobretudo, nos releases que produz para a imprensa com vistas a apresentar o IAC. Entretanto, no que diz respeito à escola alemã, o modelo de Bardi, no entender de Ethel Leon, não é a Bauhaus do período de Weimar, mas "aquela já decantada nos Estados Unidos e harmonizada com as necessidades do grande capital.", cf. Ethel Leon (2006. p. 72).

110. Não há maiores especificações dos referidos apoios, mas é possível supor que as empresas teriam dado suporte técnico para as oficinas de tecelagem instaladas museu.

111. Cf. Pietro Maria Bardi (apud Tentori, 2000, p. 49). pelo nome que os produtos recebem ou pelos textos que acompanham as imagens de moda nas revistas. Daí a preocupação em criar não só uma nomenclatura nacional para a moda, como também os textos veiculados nas revistas ${ }^{108}$.

De modo semelhante, Bardi fará uso do texto para conferir sentidos às peças da Coleção "Moda Brasileira", seja nos artigos em que defende a necessidade da criação de um vestir original e adequado ao tipo nacional, seja nos nomes escolhidos para as peças da coleção. Uma parte das peças apresentadas no desfile será inspirada e receberá nomes de origem indígena lem especial do Tupi-Guarani), como ltapetininga, Caraguatá, Poracás ou Jacaré; outros farão referência a elementos da paisagem e costumes locais, como Praias do Norte, Jangada ou Bala de Coco; ou ainda a elementos da cultura afro-brasileira como Macumba ou Mãe de Santo.

No catálogo distribuído ao público presente no desfile, nota-se a preocupação em imprimir sentido às roupas por meio do texto, pois, além do nome e material com que as peças foram confeccionadas, havia a indicação do local e situação em que tais roupas deveriam ser usadas, como, por exemplo, as tardes ensolaradas ou as manhãs no campo - o que provavelmente é um desdobramento das ideias já defendidas pelo casal Bardi e Luisa Sambonet acerca da necessidade de a moda se adequar à paisagem. Parecia, ao mesmo tempo, seguir-se, assim, um dos principais preceitos do design funcionalista propagado pela Bauhaus, "a ideia de que a forma ideal de qualquer objeto deve ser determinada pela função" 109 .

Outro ponto comum entre as políticas da Corporação e da Coleção "Moda Brasileira" é que ambas buscavam alinhar moda, indústria e comércio com preceitos nacionalistas. No caso da iniciativa brasileira, além do apoio do Mappin, então principal loja de departamentos da cidade de São Paulo, houve, conforme dito anteriormente, o apoio de quatro indústrias têxteis nacionais, as tecelagens Ribeiro industrial S.A, Industil S.A, Lutfalla S.A. e Santa Constância ${ }^{110}$.

O fato de tais roupas haverem sido produzidas em caráter comercial reforça ainda mais a impressão de que o projeto do IAC - do qual o Centro de Estudos da Moda é desdobramento, em especial, a Coleção "Moda Brasileira" -, mesmo que inspirado pelos preceitos da Bauhaus, era fruto também das ações desenvolvidas por Bardi no Brasil a partir de seu contato com as políticas fascistas para a moda e para as artes.

A busca pela "autenticidade", mencionada no texto "Problema remoto da moda", lembra o tom de uma carta enviada por Bardi a Mussolini em 30 de junho de VIII (1930), período em que atuou na Galeria de Arte de Roma, na qual menciona:

Há na ltália, hoje em dia, uma arte moderna em ascensão, valores de primeiro plano, uma ordem artística sindical notável; com esta Galeria, nós poderemos colocar à vista tudo aquilo que existe de vivo, tentar uma exportação da nossa arte, a qual sempre foi uma formidável embaixadora do nosso país (...) fazer alguma coisa de original e frutífero para a arte italiana ${ }^{111}$. 
112. Apud Lou Taylor (2004).

museu, como espaço para a educação do público em geral e também dos industriais, não era exatamente uma proposta nova, pois, segundo Louise Purbrick ${ }^{12}$, o South Kensington Museum latualmente conhecido como Victoria \& Albert Museum), iá em meados do século XIX, possuía um departamento de Artes Práticas, cujas ações educativas tinham por intenção aprimorar a manufatura e investigar os princípios do gosto. $\bigcirc$ museu inglês, voltado para as artes decorativas, pretendia fornecer subsídios à indústria local por meio do estudo de artefatos produzidos em diversos períodos e, assim, fomentar o contato com a história do design e fortalecer a indústria de artefatos inglesa. Diferente do que aconteceria no MASP, um século mais tarde, não estava no escopo do museu inglês a produção e comercialização de objetos.

Ainda que o MASP não fosse um museu de artes decorativas e, portanto, não possuísse um vasto acervo de objetos de design tal qual o museu inglês, com a implantação do IAC, Bardi pretendia colaborar na proposição de uma identidade nacional para o design produzido no Brasil e, assim, influenciar as indústrias e o gosto de público, como explica no texto de apresentação do programa do IAC escrito em parceria com Lina:

Será solicitada também a colaboração dos industriais que demonstrem interesse pelo "desenho" de suas produções, atualizando os padrões de seus produtos dentro de um gosto essencialmente contemporâneo sem se fossilizarem em tipos e estilos obsoletos. Lamentavelmente o problema do desenho industrial atualizado ainda está em seus primórdios. Muitos industriais continuam produzindo em série objetos que obedecem a um gosto passado, responsabilizando-se assim pelo baixo nível artístico que caracteriza o gosto do público. O Instituto de Arte contemporânea pretende dar uma unidade às manifestações estéticas da vida hodierna ensinando a modelar, desenhar, compor graficamente, formar tecidos, forjar cerâmicas, vidros, dentro de um espírito de progresso sempre atualizado ${ }^{113}$.

Dentre os materiais elencados acima, pelo que pude apurar, apenas os tecidos foram efetivamente desenvolvidos na escola do museu, transformados em roupas e encaminhados para a comercialização, configurando-se, portanto, no mais bem-sucedido projeto de design realizado na escola do museu ${ }^{114}$. A preocupação em propor uma identidade nacional para a moda é outra peculiaridade da Coleção "Moda Brasileira", pois não se repete em nenhuma das outras ações do IAC.

A preocupação em conferir esse caráter nacional à moda se fará presente em vários aspectos da coleção, além dos nomes, as estampas terão inspiração local. Assim, as modelos apresentaram nas passarelas vestidos com pontos riscados da umbanda, pipas usadas em brincadeiras infantis (criação de Roberto Burle Marx), sereias lemanjá (criação de Carybé) ou cerâmica marajoara (criação de Roberto Sambonet). No entanto, na maior parte das vezes, tais referências aos elementos da cultura brasileira apareciam em estampas ou padronagens não figurativas e, em
113. Caixa 1, Pasta $1(1951$ IA).

114. Em sua dissertação de mestrado, Ethel Leon (2006) cita o trecho de uma entrevista com uma exaluna do IAC, Estella Aronis, no qual ela afirma que, na condição de aluna do IAC, teria criado padronagens têxteis para a Matarazzo. Também no mesmo trabalho a pesquisadora relata que os professores do IAC indicavam os alunos para empregos e estágios, além de desenvolverem durante o curso atividades em parceria com empresas como os Cristais Prado e Lanifício Fileppo. Alexandre Wollner relatou à pesquisadora que teria realizado algumas vitrines para o Mappin em parceria com Alex Periscinotto (1925-), então diretor de publicidade da loja. 
115. No número especial da revista Habitat sobre o tema moda, o número 9, há a indicação de que os desenhos criados por Roberto Burle Marx teriam sido "realizados" por Lilli Corrêa de Araujo (19072006), artista plástica e esposa do pintor Pedro Corrêa de Araujo (18741955), mas não há maiores informações a respeito.

116. Todas as fotografias relativas à coleção da qual dispus durante a pesquisa são em preto e branco, mas, no número especial 09 da revista Habitat, há algumas descrições das cores dos tecidos e também fotografias das roupas confeccionadas, sendo assim possível aferir cores a alguns looks.

117. Em sua dissertação de mestrado, Ethel Leon afirma que não há dados que comprovem que Klara Hartoch teria sido aluna de Anni Albers, ou mesmo estudante da Bauhaus, porém, na comparação entre as padronagens criadas por Klara para o desfile "Moda Brasileira", nota-se uma visualidade bastante próxima à de têxteis criados por Anni pertencentes ao acervo do Moma.

118. "Com relação à produção industrial interna, a indústria têxtil do Brasil representava, na década de $1950,25 \%$ da força de trabalho da indústria e em torno de $20 \%$ do valor da produção industrial." Cf. Durval Coan e Anita Kon (1950). alguns casos, bastante próximas daquelas elaboradas por Anni Albers e Gunta Stölz (1897-1983), professoras de Tecelagem da Bauhaus ${ }^{115}$.

$\bigcirc$ "rio grande" que dá origem ao vestido Iguassu, por exemplo, é caracterizado pela mescla de cores (aparentemente obtida a partir da trama do tecido), que gera pequenos riscos em verde esmeralda, azul marinho e azul claro $^{116}$. Já o vestido Tangerina, inspirado em fruta exótica, mas encontrada em abundância no país, o que gerou sua associação à ideia de brasilidade, era confeccionado em algodão preto com grandes motivos laranjas na padronagem. Ambos os vestidos são criações de Klara Hartoch ${ }^{17}$.

Em outros casos, a associação com o nacional aparece nos materiais usados nas roupas e acessórios (sapatos e chapéus apresentados no desfile foram produzidos nas oficinas do MASP, bem como alguns botões que compunham as peças), como os tecidos do vestido Balaio (Figura 7), inspirados na cestaria indígena, com a seguinte composição: mescla de algodão vermelho, laranja, roxo e azul com trançado de palha e algodão e ráfia cor de mel (criação de Klara Hartoch), ou os vários vestidos confeccionados em algodão, então o principal tecido produzido no Brasilli18.

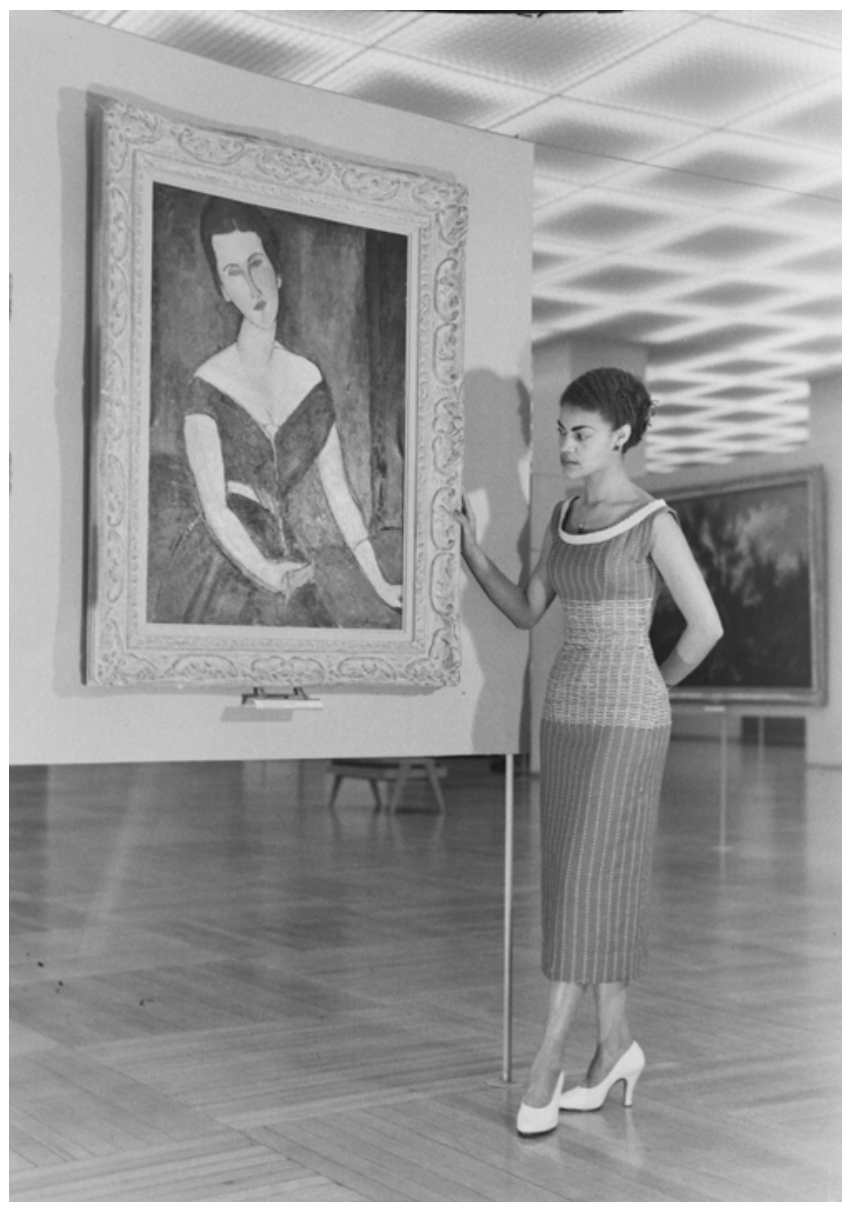

Figura 7: Modelo brasileira Glória traja vestido "Balaio" (Coleção "Moda Brasileira", 1952) e posa para foto diante da obra Madame G. van Muyden de Amadeo Modigliani, 1916-1917, pertencente ao acervo do MASP. Biblioteca e Centro de Documentação do MASP. 
Mesmo intuitivamente, Bardi e o grupo que atuava no IAC recuperam em suas ações a ideia propagada pelo modernismo brasileiro para o qual "só seremos modernos, se formos nacionais" 119.

No Brasil, Bardi ressignifica a experiência fascista, que somada aos ideiais da Bauhaus e seu olhar estrangeiro sobre o país, acaba por aproximá-lo dos ideais modernistas. Em outras palavras, o projeto para a moda brasileira é gerado a partir de sua experiência e formação internacional e a Coleção "Moda Brasileira" seria exemplo da aproximação com as propostas modernistas, posto que, por meio da coleção. Pretendia-se inserir o Brasil na "contemporaneidade universal vigente, sem o sacrifício das peculiaridades características, de seus legítimos valores, através de uma tomada de consciência, em profundidade da realidade nacional" ${ }^{\prime \prime 20}$.

Ainda que não seja objetivo desse artigo aprofundar a relação do MASP com o Modernismo, é pertinente lembrar que Bardi associa o museu como um desdobramento do projeto modernista, tal como expressa no catálogo da exposição Semana de 22: "O Museu de Arte de São Paulo foi fundado em 1946 e aberto ao público no ano seguinte, por iniciativa de Assis Chateaubriand, constituiu o primeiro fato museográfico apreciável como consequência da Semana de $22^{\prime \prime} 121$.

Apesar da sensibilidade do olhar estrangeiro para os temas de cunho nacional que inspiraram a coleção - Pietro Maria Bardi, Roberto e Luisa Sambonet eram italianos; Carybé, argentino e Klara Hartoch, alemã, ou seja, do grupo que atuou na concepção da coleção apenas Roberto Burle Marx era brasileiro -, a cultura popular e o folclore já eram, pelo menos desde o Modernismo nos anos 1920 e especialmente a partir da década de 1930, temas visitados e debatidos pelas artes plásticas e por intelectuais brasileiros, ou nas palavras de Mônica Velloso, "altamente mobilizadores para as gerações de intelectuais das décadas de 1930-1940"122.

Tais temáticas também foram exploradas pelo Estado. Durante a década de 1940, por exemplo, as tradições populares, as paisagens e a cultura afrobrasileira, entre outros, eram alguns dos principais assuntos registrados nas fotografias que Marcel Gautherot (1910- 1996) produzia para o Serviço do Patrimônio Histórico Artístico e Cultural (Sphan). Estas, assim como outras séries fotográficas realizadas nas décadas de 1930 e 1940, muitas vezes com o apoio de instituições públicas e governamentais, "recriam e estabilizam representações que vinham sendo escolhidas e convencionalizadas nas descrições textuais e iconográficas desde o século XIX"123.

$\mathrm{Na}$ década de 1940-1950, essas imagens foram massivamente difundidas no país graças ao fotojornalismo, sobretudo, da revista $\bigcirc$ Cruzeiro, que, por seu alcance nacional e grandes tiragens, constituía importante espaço de difusão de determinada ideia de identidade nacional, a qual, na visão de Assis Chateaubriand, era baseada "no exotismo das paisagens e do povo mestiço", e, em especial, nos índios, entendidos pelo empresário como o grande símbolo do
119. Cf. Renato Ortiz (1999, p. 35).

120. Cf. Paulo Mendes de Almeida (1972).

121. Em 1972, Bardi organizou no MASP a exposição "Semana de 22: antecedentes e consequências" em comemoração aos 50 anos da semana de 1922 . No catálogo da mostra, o MASP, juntamente com o MAM e a Bienal são listados como algumas das "consequências" do movimento modernista. Ver Semana de $22 \ldots$ (1972, s.p.).

122. Cf. Mônica Velloso (2001, p. 8). Segundo Carlos Guilherme da Motta, "Durante o Estado Novo (1937-1945) consolida-se nos aparelhos ideológicos do Estado e fora deles uma concepção nacionalista de Cultura Brasileira: no ensino, na rede de bibliotecas, nas interpretações de ideólogos do porte de Fernando de Azevedo, Sérgio Buarque de Holanda, Gilberto Freyre e Afonso Arinos, na concepção de Patrimônio Histórico e Artístico Nacional, etc.”. Cf. Carlos Guilherme da Mota (1990, p. 20). Sobre o tema ver também Antônio Candido (2000); Sérgio Miceli (2001) e Hermano Vianna (2004).

123. Cf. Lygia Segala (2005, p. 92). 
124. Cf. Marlise Meyrer (2012, s.p.).

125. Se, por um lado, as imagens de O Cruzeiro reforçam a presença do índio no país e, por conseguinte, a ideia do Brasil como um país mestiço, por outro, a revista estava engajada no projeto nacional que pregava a dominação dos índios, "vista não só como inevitável, mas como necessária à modernização do país". Cf. Sérgio Burgi e Helouise Costa (2013).

126. Cf. Helouise Costa (2013).

127. Cf: Néstor Garcia Canclini, 2006.

128. Refiro-me a exótico no sentido que Victor Segalen (2002) confere à palavra, que estaria, de modo geral, associado ao "outro", ou àquilo que, por ser diferente, é difícil de ser compreendido. Para o autor, o exotismo é visível especialmente em três situações: o exotismo geográfico, no qual a distância do "outro" é determinada a partir da distância espacial, frequentemente resultando em diferenças étnicas e culturais; o exotismo temporal, que se caracterizaria a partir de um passado ou futuro idealizados; o exotismo sexual, em que a diferença se dá sem que haja um afastamento espacial ou temporal. Este diria respeito à eterna incompreensão do outro, como, por exemplo, as diferenças entre masculino e feminino. Partindo desse raciocínio é possível pensar que haja estranhamento e distanciamento entre culturas dentro de um mesmo território. Por exemplo, o Brasil dos índios, das paisagens amazônicas e da cultura afro-brasileira muitas vezes mostrado nas páginas de $O$
Brasil ${ }^{123}$. Índios das mais diversas tribos apareciam com frequência em reportagens veiculadas em O Cruzeiro entre as décadas de 1940-1950'25. As religiões, bem como a natureza enaltecida, temas bastante explorados na Coleção "Moda Brasileira", também eram comumente abordados nas fotorreportagens da citada revista. ${ }^{126}$

Mas, se tais imagens ajudavam a vender revistas, talvez, quando associadas à moda, fossem vistas como demasiadamente "exóticas" no sentido de caminharem na direção oposta àquilo que era entendido como moda pelos brasileiros naquele momento. Se a moda francesa propagava luxo e sofisticação, as roupas com padronagens e elementos que exploravam os temas nacionais remetiam ao "outro" dentro do próprio território, ou ao popular como aponta Canclini ${ }^{127}$ no sentido de "exclú́do"128. No entender de Victor Segalen, exótico seria aquilo que é estranho e difícil de ser compreendido, no caso, o próprio uso de elementos que, apesar de nacionais, tais como a paisagem, as culturas indígenas e afro-brasileiras, eram vistos como estranhos pelas elites consumidoras de moda (e para quem a Coleção "Moda Brasileira" se dirigia).

Ou seja, de um lado, havia a alta-costura como principal polo difusor de moda, sendo suas marcas consideradas dominantes na competição pelo mais alto prestígio no campo da moda ${ }^{129}$. De outro, a Coleção "Moda Brasileira" e sua tentativa de "subversão" desse campo através da apresentação de peças inspiradas na Macumba, Mãe de Santo, Favela ou Urubu' ${ }^{130}$. Ainda que Bardi recuperasse o popular no sentido de quebrar com as oposições vigentes nas sociedades modernas, como moderno/tradicional, culto/popular, a empreitada provavelmente não gerou os resultados esperados ${ }^{131}$.

Não há dados disponíveis acerca das vendas das peças da coleção, ou seja, não é possível determinar precisamente se a iniciativa foi um sucesso ou um fracasso de vendas. Como vimos anteriormente, os relatos de Bardi sobre o tema eram de modo geral contraditórios. De certo, sabemos que a iniciativa não se repetiv e as casas de moda continuaram a vender cópias e originais da altacostura para a clientela de luxo. As mulheres das camadas médias seguiram a imitando os lançamentos da moda de Paris e até da ltália. Nos anos 1950, os costureiros italianos das mais afamadas casas de moda começam a ganhar destaque internacional graças à divulgação de suas produções em revistas, o que dava às leitoras a oportunidade levar seus modelos para modistas ou costureiras. Carambolas, cachoeiras, jangadas e o "vento na varanda" não chegaram ao guarda-roupa nacional, pelo menos não naquele momento.

\section{Considerações finais}

Em 1967, ao fazer um balanço dos primeiros vinte anos de atividade do MASP, Bardi escreveu "O Museu de Arte (...) ofereceu alguns subsídios na formação da metrópole e operou para desprovincializar uma área que ainda hoje precisa de atenção (...)". No mesmo texto, ironizava longamente a questão do 
gosto decorativo dos brasileiros e prosseguia explicando que, dentre outras atividades, o industrial design teve, naquele momento, sua primeira escola no país. Ou seja, no entender de Bardi, a metrópole só se desenvolveria plenamente a partir do momento que a produção dos bens fosse orientada pelo conhecimento do design

As atividades ligadas à área de design, desenvolvidas no museu em seus primeiros anos de funcionamento, e em especial à moda, seriam lembradas por Bardi nos diversos livros sobre a história do museu escritos durante sua vida. Em 40 anos de MASPI32, doze fotografias ilustram o tema, mostrando desde as oficinas do Centro de Estudos da Moda até fotos dos desfiles lá realizados, da vitrine do Mappin expondo as roupas produzidas no MASP e do ilustrador e designer de moda Alceu Penna, ladeado por duas modelos da Rhodia, no saguão do museu, por ocasião da exposição das peças doadas pela empresa em $1971^{133}$.

Já em A Pinacoteca do MASP Bardi (1982) explica que, no início das atividades do MASP, sua proposta para o museu afrontava o conservadorismo ao ofertar, entre outros, cursos regulares na área de cinema, artes plásticas, música, dança, design, fotografia, leitura teatral, propaganda e jardinagem. Ele diz:

O plano se baseava na unidade das artes, com a inclusão de manifestações culturais consideradas à margem. Então, pela primeira vez assistiu-se numa Pinacoteca a desfiles de moda, inclusive de moda brasileira produzida nos ateliers das escolas: desenhada, tecida, confeccionada e desfilada no museu ${ }^{134}$.

As roupas criadas no museu extra4olaram, portanto, o limite da instituição, posto que, além de terem contado com o apoio de indústrias têxteis para sua produção, saíram do museu para a loja de departamentos, concretizando de forma original o eixo do pensamento de Bardi le aí noto a influência da proposta de Walter Gropius para a Bauhaus), ou seja, "restabelecer" (ou, no caso, estabelecer) "o contato entre o mundo da arte e o mundo da produção"135.

Os mundos da arte e da produção industrial eram, no entender de Bardi, bastante próximos, ou "um só", como evidencia sua declaração ao jornal Correio do povo por ocasião da realização do Desfile de Moda Industrializada no museu em outubro de 1971: "Moda é arte. Arte ao alcance de todos. Arte de comunicação direta na vida. Moda é arte do cotidiano. A moda é a célula mãe do estilo. $\bigcirc$ estilo é elemento que forma a história da arte. Portanto, a moda faz parte da arte" $^{\prime \prime} 136$.

Para mensurar com mais precisão o impacto das ações de Bardi em relação à moda é preciso lembrar a Seção de Costumes. Ainda que ele não mencione a existência do acervo de indumentária nos livros que contam a história do museu, essa coleção, apesar de exígua, acabou por ganhar centralidade no que diz respeito à História da Moda Brasileira. Isso porque, após a incorporação do acervo da Rhodia em 1971, o museu se tornou um dos poucos no país a conservar roupas produzidas com vistas a propor uma visualidade brasileira para a moda. As peças integrantes da coleção da Rhodia que chegou ao acervo do
Cruzeiro nas décadas de 1940-1960, para muitos de seus leitores, era provavelmente um país exótico, posto que diverso daquele que conheciam e que aceitavam como "civilizado".

129. Ver Pierre Bourdieu (1983).

130. Segundo Pierre Bourdieu (1983), a subversão de valores estabelecidos seria a forma utilizada pelos recémchegados ao campo para ocupar algum espaço.

131. Ver Nestor Garcia Canclini (2006, p. 205).

132. Ver Pietro Maria Bardi (1986)

133. Alceu de Paula Penna (1915-1980) ficou conhecido por seu trabalho na revista $O$ Cruzeiro para a qual criava semanalmente ilustrações para a seção Garotas (1938-1964) e de Moda (1941-1964). Desde a década de 1930 até 1946 , atuou também como figurinista para shows apresentados em cassinos, e, após esse período, prosseguiu criando figurinos para peças de teatro e outros eventos. Sua experiência como ilustrador de moda o levou a atuar como estilista na década de 1960, desenhando coleções para a Rhodia Têxtil, algumas dessas peças pertencem hoje ao acervo do MASP. Segundo informações do Acervo do MASP há, na Coleção da Rhodia, 5 peças que teriam sido desenhadas por Alceu Penna para a Rhodia.

134. Cf. Pietro Maria Bardi (1982, p. 9).

135. Cf. Giulio Carlo Argan (1992, p. 29).

136. Cf. Correio do Povo (27/10/1971). Na ocasião foram exibidas no museu coleções masculinas 
pertencentes ao Consórcio Brasileiro de Moda Masculina (Camelo, Chester, Epsom, Patriarca, Regência, Renner, Sparta e Vila Romana) e moda feminina (Campos do Jordão, Cori, General Modas, Imperchic, Lanover, Le Mazelle, Pull-Sport, Ruri-ta, Sonia Coutinho, Tomaso e Tricot-Lã). O evento foi uma promoção do Museu em convênio com o Governo do Estado de São Paulo através da Secretaria de Turismo e Conselho Estadual de Cultura. Os desfiles foram acompanhados de apresentações musicais do Laboratório Musical do MASP e no intervalo foi realizado um "happening" pelos virtuoses da gaita escocesa do Royal Caledonian Band. Cf. Convite para o Desfile de Moda Industrializada.

137. Ao realizar uma busca com a palavra indumentária no Cadastro Nacional dos Museus, disponível no site do Sistema Nacional de Museus, foi possível detectar que, em 2008, o Brasil possuía pelo menos 79 museus que tinham coleções ou pelo menos peças de roupas em seu acervo. (SILVA, 2008) Não é possível repetir a pesquisa atualmente, pois a base em questão (http://sistemas. museus.gov.br/cnm/ pesquisa/filtrarUf, acessado em: 17 fev. 2014) passou por reformulação e a pesquisa por tipologia de materiais não está mais disponível. Uma busca recente realizada a partir de palavras-chave como moda e indumentária apresentou como resultado três museus, são eles: Museu da Indumentária e da Moda (Virtual), Museu da Moda de Canela (composto exclusivamente de réplicas e dedicado à história da indumentária ocidental) e Museu do Têxtil e da Moda da Universidade Regional de Blumenau (em cujo site
MASP seria também um desdobramento das propostas da Coleção "Moda brasileira", uma vez que, em ambas, as inspirações da estética marajoara, das religiões afro-brasileiras, bem como da fauna e flora locais se faziam presentes ${ }^{137}$.

O acervo e, em especial, a coleção da Rhodia acabaram se tornando uma espécie de referência para a moda brasileira. Essa parecia ser a intenção de Bardi ao propor, quando de sua doação, que as peças fossem exibidas no museu sob o nome "Retrospectiva da Moda Brasileira". Ao musealizar as peças, Bardi reforça as marcas dos significados que anteriormente lhes foram atribuídos pela publicidade da Rhodia - cujo propósito era associar essas peças a uma qualidade internacional e artística da moda brasileira. Tais significados são recolocados por Bardi no ato da musealização, no título que confere à exposição e também nos releases que escreve para a imprensa. $\bigcirc$ trecho extraído do jornal Cidade de Santos em matéria intitulada "Em exposição toda a história da moda brasileira" é exemplo:

Há doze anos não existia a moda brasileira. Somente os privilegiados podiam se apresentar com roupas que tivessem um quê de moda. Os tecidos nacionais não mereciam confiança. As revistas brasileiras dedicavam páginas e páginas às revistas europeias e norte-americanas, completamente divorciadas das necessidades e padrão de estética do nosso consumidor. Em 1970 a situação mudou completamente. A moda brasileira tornou-se realidade, os grandes manequins passaram a receber o devido respeito profissional e muitos iniciaram no Brasil uma carreira que os projetou no mundo da moda internacional ${ }^{138}$.

Essa coleção, em seu todo ou parcialmente, foi exposta em diversas mostras, cujo objetivo era celebrar a moda brasileira e atribuir às peças da coleção a "gênese" da busca de uma identidade nacional. $\bigcirc$ que o interesse por tal coleção revela é que, ao reconhecermos que, no passado, produzimos uma moda que, ao invés de calcar-se exclusivamente na cópia e adaptação de elementos estrangeiros, explorou, ao menos em suas estampas, elementos associados à nossa "comunidade imaginada"139, talvez possamos dizer que nossa moda, ainda que recente, tem uma história, ou uma "representação do passado", preservada pelo museu $^{140}$.

\section{REFERÊNCIAS}

\section{ACERVO MASP}

Carta de P.M. Bardi a Agnes Sabbagh, 02/12/1975.

Carta de P.M. Bardi ao sr. Ariel Chaves, 07/03/1983.

Carta de P.M. Bardi a Alexandre Figueira Rodrigues, 27/04/1983.

Carta de Alexandre Figueira a P.M. Bardi (sem data). 


\section{BIBLIOTECA E CENTRO DE DOCUMENTAÇÃO DO MASP}

1951- IAC - Caixa 1 - Pasta 1

1951 - Desfile de Costumes - Caixa 4

\section{Pasta 22}

Release para a imprensa, documento 32 .

Release para a imprensa, documento 07.

Material para a imprensa, documento 29.

Pasta 23

Material para a imprensa, documento 02.

\section{Caixa 3.1 - Pasta 15}

1951 - Conferência sobre elegância e moda -

Marcel Rochas no Museu, documento 5.

\section{Catálogos}

Traje: um objeto de arte, 18 a 30 de agosto de 1987, Rio de Janeiro: Rio Design Center.

Traje: um objeto de arte, 7 a 26 de julho de 1987, São Paulo: MASP.

Primeiro desfile de Moda Brasileira, 6 de novembro de 1952, São Paulo: MASP.

\section{Convite}

Desfile de Moda Industrializada, 28 de outubro de 1971.

\section{ARTIGOS VEICULADOS NA IMPRENSA}

A união faz a indústria da moda. Veja, São Paulo, 29 mar. 1972, p. 53-57.

Bardi: um livro para resgatar a memória do trem de ferro. Folha de S. Paulo, São Paulo, 9 dez. 1983, p.37.

Desfilarão hoje no Rio quatro famosos manequins de Paris. Diário de S. Paulo, São Paulo, 29 mar. 1951.

Desfile de modas deste e de outros tempos: Esplendor da costura francesa na passarelle instalada no Museu de Arte. Folba da Manhã, Caderno Vida Social e Doméstica, São Paulo, 1 abr. 1951, p. 1.

Editais: Instituto de pensão e aposentadorias de industriais. O Estado de S. Paulo, São Paulo, 3 fev. 1952, p. 21. há poucas informações sobre o acervo, mas é provável que o foco seja a indústria têxtil da região). Entretanto, outros importantes museus nacionais possuem acervos de indumentária. São eles; o Museu do Traje e do Têxtil, pertencente ao Instituto Feminino da Bahia, especializado em indumentária e que abriga especialmente peças de alta-costura internacional, trajes de baianas e trajes eclesiásticos (informação obtida a partir de visita realizada ao museu em 2007 e também a partir do catálogo da coleção [Museu do Traje e do Têxtil, 2003]); o Museu Histórico Nacional, que possui uma coleção de uniformes de trabalho e também um acervo de indumentária que reúne roupas da família real e nobreza nacional do século XIX e peças de alta moda do século XX (como pude verificar através de visita realizada à reserva técnica daquela instituição em 2003) e o Museu Paulista, que, segundo o técnico responsável pelo setor, Adilson José de Almeida, reúne fardamentos militares, trajes de altacostura e trajes étnicos.

138. Cf. Cidade de Santos (26/11/1971).

139. Cf. Benedict Anderson (2008).

140. Cf. Pierre Nora (1993, p. 9). 
Em exposição toda a história da moda brasileira. Cidade de Santos, Santos, 26 nov. 1971.

Lançamentos da Moda Brasileira. Folha da Manhã, Caderno Vida Social e Doméstica, São Paulo, 9 nov. 1952, p. 7.

MENGOZZI, Frederico. Professor "do nada" constrói marco da cultura brasileira. Folha de $S$. Paulo, 2 out. 1999, p. 2.

Moda brasileira (publicidade). Folha da Manhã, Caderno Assuntos Gerais do Dia, São Paulo,5 nov. 1952, p.5.

Pietro Maria Bardi. Jeans e Sportwear, ano 1, n. 2, 1982, p.24-25.

Sem título. Estado de S. Paulo, São Paulo, 20 maio 1976, p. 20.

Traçou novos rumos para a elegância feminina o desfile de modelos de inspiração brasileira. Diário da Noite, Rio de Janeiro, 10 nov. 1952, p. 11.

Três séculos de moda em desfile. Diário de S. Paulo, São Paulo, 18 mar. 1951.

Visão retrospectiva da moda desde a época feudal até hoje., Diário de S. Paulo, São Paulo, 7 mar. 1951.

\section{LIVROS, ARTIGOS E TESES}

ADVERSE, Angelica. Moda: moderna medida do tempo. O Futurismo italiano e a estética do efêmero. Bauru: Estação das Letras e Cores, 2012.

ARGAN, Giulio Carlo. Arte moderna. Do iluminismo aos movimentos contemporâneos. São Paulo: Companhia das Letras, 1992.

ARRUDA, Maria Arminda do Nascimento Metrópole e cultura: São Paulo no meio do século XX. Bauru: EDUSC, 2001.

AUGRAS, Monique. História oral e subjetividade. In: SIMSON, Olga Rodrigues de Moraes von. Os desafios contemporâneos da História Oral. Campinas: Centro de Memória, Unicamp, 1997, p. 27-38.

BARDI, Pietro Maria. Problema remoto da moda. Habitat: revista das artes do Brasil, out.-nov. 1952, p. 65

. MASP, Assis Chateaubriand, Ano 30. São Paulo: Secretaria de Cultura, Ciência e Tecnologia do Governo do Estado, 1978.

Museu de Arte de São Paulo. São Paulo: Edições Melhoramentos, 1978.

. A Pinacoteca do MASP de Rafael a Picasso. São Paulo: Banco Safra, 1982. 40 anos de MASP. São Paulo: s.e., 1986.

História do MASP. São Paulo: Instituto Quadrante, 1992.

Pequena História da Arte: introdução aos estudos das artes plásticas. São Paulo: Melhoramentos, 1993. 
BRAGA, João; PRADO, Luis André do. História da Moda no Brasil. $2^{a}$ ed. São Paulo: Disal, 2011.

BONADIO, Maria Claudia. Dignidade, celibato e bom comportamento: relatos sobre a profissão de modelo e manequim no Brasil dos anos 1960. Cadernos Pagu. Campinas, n. 22, p. 47-81, 2004.

O fio sintético é um show: moda, política e publicidade (Rhodia S.A. 19601970). Tese (doutorado em História) - IFCH/Unicamp, Campinas, 2005.

BOURDIEU, Pierre. Alta-costura e alta-cultura. In: Questões de Sociologia, Rio de Janeiro: Marco Zero, 1983, p. 154-161.

BURGI, Sérgio; COSTA, Heloise. A temática indígena. In: As origens do fotojornalismo no Brasil. Um olhar sobre O Cruzeiro, 1940-1960. São Paulo: Instituto Moreira Salles, 2012, p. 42-77.

CANCLINI, Nestor Garcia. Culturas híbridas. São Paulo: Edusp, 2006.

CANDIDO, Antônio. Literatura e cultura, 1900-1945 (Panorama para estrangeiros). In: Literatura e Sociedade. São Paulo: Publifolha, 2000, p. 101-126.

CARDOSO, Rafael. Uma introdução à história do design. São Paulo: Edgard Blücher, 2004.

CHOAY, Françoise. A alegoria do patrimônio. São Paulo: Estação Liberdade/ Editora UNESP, 2001.

COAN, Durval Calegrari; KON, Anita. Transformações da indústria têxtil brasileira: a transição para a modernização. Revista de Economia Mackenzie, São Paulo, v. 3, n. 3, p. 11-34, 2005.

COSTA, Helouise. Entre o local e o global: a invenção da revista O Cruzeiro. In: BURGI, Sérgio; COSTA, Helouise. As origens do fotojornalismo no Brasil. Um olhar sobre O Cruzeiro, 1940-1960. São Paulo: Instituto Moreira Salles, 2012, p. 9-32.

CRANE, Diana. Moda e artificação: vanguarda ou patrimônio? In: Ensaios sobre moda, arte e globalização. São Paulo: Senac, 2011.

CRISPI, Ana Paula Lobo. O Costume do ano de 2045 de Salvador Dalí: a história de um vestido, In: PAULA, Teresa Cristina Toledo de (org.). Tecidos e sua conservação no Brasil: museus e coleções. São Paulo: Museu Paulista da USP, 2006.

FALBEL, Anat. Peter Scheier: visões urbanas de um fotógrafo moderno na América. In: Anais do $7^{\circ}$ Seminário Docomomo, Porto Alegre, 2007. Disponível em: http://www.ufrgs.br/ docomomo/seminario\%207\%20pdfs/006.pdf, acessado em 7 maio 2014.

GONÇALVES, José Reginaldo. Os limites do patrimônio. In: BELTRÃO, Jane Felipe; ECJERT, Cornélia.; FERREIRA FILHO, Manuel (Orgs.). Antropologia e patrimônio cultural. Diálogos e desafios contemporâneos. Blumenau: Nova Letra, 2007, p. 239-246.

HAYE, Amy de la; MENDES, Valerie. A moda do século XX. São Paulo: Martins Fontes, 2003.

LAVER, James. Style in Fashion. Oxford: Oxford Univeristy Press, 1949. 
LEON, Ethel. IAC. Instituto de Arte Contemporânea. Escola de Desenho Industrial do MASP (1951-1953). Dissertação (Mestrado) Faculdade de Arquitetura e Urbanismo, Universidade de São Paulo, São Paulo, 2006.

LIPOVETSKY, Gilles. O império do efêmero. A moda e seus destinos nas sociedades modernas. São Paulo: Companhia das Letras, 1989.

MALERONKA, Wanda. Fazer roupa virou moda: um figurino de ocupação da mulher, São Paulo 1920-1950. São Paulo: Senac, 2007.

A Moda no Brasil. Habitat: revista das Artes no Brasil, São Paulo, abr.-jul. 1952.

MENESES, Ulpiano Toledo Bezerra A exposição museológica e o conhecimento histórico. In: FIGUEIREDO, Betânia Gonçalves;VIDAL, Diana Gonçalves. Museus: do gabinete de curiosidades à museologia moderna. Belo Horizonte: Argumentvm; Brasília: CNPq, 2005, pp. 15-84.

MEYRER, Marlise Regina. Natureza e identidade nacional nas páginas da revista O Cruzeiro na década de 50. In: Anais do XVIII Encontro Regional de História / Anpuh, Mariana, 2012. Disponível em <http://www.encontro2012.mg.anpuh.org/resources/anais/24/1340650252_ ARQUIVO_NaturezaeidentidadadeAMPUHMG.pdf>, acessado em 8 maio 2014.

MICELI, Sérgio. Intelectuais à brasileira. São Paulo: Companhia das Letras, 2001.

MORSE, Richard. Formação histórica de São Paulo. São Paulo: Difel, 1970.

MOTA, Carlos Guilherme da. Cultura brasileira ou cultura republicana? Estudos Avançados, São Paulo, v. 4, n. 8, p. 19-38, 1990.

NEIRA, Luz Garcia. Estampas na tecelagem brasileira. Da origem à originalidade. Tese de doutorado em Arquitetura - Faculdade de Arquitetura da Universidade de São Paulo, 2012.

NORA, Pierre. Entre memória e história: a problemática dos lugares. Projeto História. São Paulo, v.10, p. 7-28, 1993.

ORTIZ, Renato. A moderna tradição brasileira. São Paulo: Brasiliense, 1999.

PALMER, Alexandra. Dior: A New Look, a New Enterprise (1947-1957). Londres: V\&A Publishing, 2009.

PARKINS, Ilya. Poiret, Dior and Schiaparelli: Fashion, Femininity and Modernity. Londres/ Nova York: A\&C Black, 2013.

PAUliCElli, Eugênia. A escrita da moda sob o Regime Fascista: Dicionário italiano e o Comentário de Moda de Cesare Meano e Contos de Gianna Manzini e Alba de Cespedes. In: Fashion Theory: a revista da Moda, Corpo e Cultura, São Paulo, v. 3, n. 1, 2004.

QUEIROZ, Fernanda. Os estilistas: Fiala; Nunes; Guimarães; Esper; Issa; Segreto; Rodrigues; Hercovitch. São Paulo: SENAI/CETEVEST, 1998. (Coleção: O mundo da moda).

RUBINO, Silvana Barbosa. Rotas da modernidade: trajetória, campo e história na atuação de Lina Bo Bardi 1947-1968. Tese (doutorado em História) - IFCH/Unicamp, Campinas, 2002.

Corpos, cadeiras, colares: Charlotte Perriand e Lina Bo

Bardi. Cadernos Pagu, Campinas, n. 34, p. 331-362, 2010. 
RUBINO, Silvana. GRINOVER, Marina; (orgs.). Lina por escrito. Textos escolhidos de Lina Bo Bardi. São Paulo: Cosac Naif, 2009.

SAMBONET, Luisa. Uma moda brasileira. Habitat: revista das Artes do Brasil, São Paulo, out.-nov. 1952.

SANT'ANNA. Patrícia. Coleção Rhodia: Arte e design de moda nos anos sessenta no Brasil. Tese (doutorado em História da Arte) IFCH/Unicamp, Campinas, 2010.

SANTOS, Myrian Sepúlveda dos. Políticas da memória na criação dos museus brasileiros. Cadernos de Sociomuseologia, n. 19, 2002, pp. 99-119.

SEGALEN, Victor. Essay on Exoticism: An Aesthetics of Diversity. Londres: Duke University Press, 2002.

Semana de 22: antecedentes e consequências. São Paulo: Museu de Arte de São Paulo/ Governo do Estado de São Paulo/ Secretaria de Cultura, Esportes e Turismo, Conselho Estadual de Cultura, 1972.

SEIXAS, Cristina. A questão da cópia e da interpretação no contexto da produção de moda da Casa Canadá, no Rio de Janeiro na década de 50. Dissertação (Mestrado), PUC-RJ, Rio de Janeiro, 2002.

SHAPIRO, Roberta. O que é artificação? Sociedade e Estado. Brasília, vol. 22, n. 1, p. 135-151, 2007.

STERN, Radu. Against Fashion. Massachusetts: Massachusetts Institute of Technology, 2004.

SILVA, Fernanda Marochi. Vínculos entre moda e museu no cenário nacional. In: Anais do $4^{\circ}$ Colóquio de Moda, Novo Hamburgo, 2008. Disponível em: <http://www.coloquiomoda. com.br/anais/anais/4-Coloquio-de-Moda_2008/39318.pdf>, acessado em 17 fev. 2014.

STOLARSKY, André. Alexandre Wollner e a formação do design moderno no Brasil. São Paulo: Cosac \& Naif, 2005.

SUDJIC, Deyan. A linguagem das coisas. Rio de Janeiro: Intrínseca, 2010.

SVENDSEN, Lars. Moda: uma filosofia. Rio de Janeiro: Jorge Zahar, 2010.

TAYLOR, Lou. Establishing Dress History. Manchester/Nova York: Manchester University Press, 2004.

TENTORI, Francesco. P.M. Bardi: com as crônicas artísticas do "L’Ambrosiano" 1930-1933. São Paulo: Instituto Lina Bo e P.M. Bardi/Imprensa Oficial do Estado, 2000.

VEBLEN, Thorstein. The Economic Theory of Women's Dress. In: MESTROVIC, Sjepan. Thorstein Veblen on Culture and Society. Londres, Sage Publications, 2003. APUD: GONZALES, Ana Marta. A contribuição de Thornstein Veblen para a teoria da moda. Iara: Revista de Moda, Cultura e Arte, São Paulo, v. 1, n. 1, p. 22-77, 2008.

VELlOSO, Mônica Pimenta. Do Guarani ao Guaraná. Rio de Janeiro: Casa de Rui Barbosa e Ministério da Cultura, 2001.

VIANNA, Hermano. O mistério do samba. Rio de Janeiro: Jorge Zahar Editores/UFRJ, 2004. 
WOOD, Ghislaine. The Surreal Body: Fetish and Fashion. Londres: Victoria \& Albert Museum, 2007.

\section{SITES CONSULTADOS}

http://sistemas.museus.gov.br/cnm/pesquisa/filtrarUf

http://www.inter-disciplinary.net/wp-content/uploads/2009/08/Lo-Sicco-paper.pdf.

http://www.itaucultural.org.br/aplicexternas/enciclopedia_ic/index.cfm?fuseaction=marcos_ texto\&cd_verbete $=4272$,

http://www.vice.com/read/fashions-forgotten-fascists

http://www.vogue.it/en/encyclo/fashion/t/turin-and-fashion,

Artigo apresentado em 05/2014. Aprovado em 11/2014. 